\title{
Maahanmuuttovastaisen ideologian ja ryhmäidentiteetin rakentuminen Suomi24-keskustelussa
}

\author{
Simo Mä̈̈ttä, Karita Suomalainen ja Ulla Tuomarla
}

\section{Johdanto}

Verkossa leviävä vihapuhe on yhteiskunnallinen ongelma, jonka ratkaisemiseksi tarvitaan monen eri alan asiantuntemusta. Kielentutkimuksessa vihapuheeseen on kuitenkin kiinnitetty toistaiseksi vain vähän huomiota. Kansainvälisesti vihapuhetta on tutkittu erityisesti kriittisen diskurssintutkimuksen parissa (viimeaikaisesta tutkimuksesta ks. esim. Assimakopoulos, Baider \& Millar toim. 2017; LewandowskaTomaszczyk 2017). Suomessa harvoja vihapuhetta fennistiikan näkökulmasta käsitelleitä tutkimuksia ovat Vitikan (2014) pro gradu -tutkielma, jossa kielitieteellistä ja oikeustieteellistä näkökulmaa yhdistellen tarkastellaan neljää rangaistavaksi vihapuheeksi tuomittua internetin tekstiä, sekä Lahden (2019) väitöskirja, joka käsittelee maahanmuuttokeskustelun retoriikkaa Suomi24-verkkofoorumilla. Vihapuhetta sivuaa myös Herneahon (2018) tutkimus, jossa tarkastellaan maahanmuuttodiskurssia eduskuntapuolueiden vaalimateriaaleissa. Suomalaisessa kontekstissa kielentutkimusta aktiivisemmin vihapuhetta on tarkasteltu esimerkiksi mediatutkimuksen puolella (ks. esim. Pöyhtäri, Haara \& Raittila 2013; Kaján 2017; Paakkinen 2017; Saresma 2012, 2017).

Tässä artikkelissa pyrimme omalta osaltamme edistämään vihapuheen tutkimusta kielitieteellisestä näkökulmasta suomalaisessa ja suomenkielisessä kontekstissa. ${ }^{1}$ Tarkastelemme Kielipankissakin saatavilla olevan Suomi24-keskustelufoorumin ${ }^{2}$ maahanmuuttokriittisen keskustelun kielellisiä piirteitä tapaustutkimuksen pohjalta. Tutkimuksemme aineistona on Suomi24-keskustelufoorumilla käyty keskustelu, jonka aloitti nimimerkki henkilöysässä 1. lokakuuta 2017 otsikolla Kauanko muslimeja

1. Artikkeli on syntynyt kirjoittajien tasavertaisen yhteistyön tuloksena, mistä kertoo nimien aakkosjärjestys. Johdannon (luku 1), verkkovuorovaikutusta käsittelevän aiemman tutkimuksen kuvauksen (luku 2) ja johtopäätökset (luku 5) olemme kirjoittaneet yhdessä. Karita Suomalainen ja Ulla Tuomarla ovat vastanneet luvussa 3 kuvattujen intratekstuaalisten ilmiöiden analyysista. Simo Määttä puolestaan on ollut vastuussa luvussa 4 kuvattujen intertekstuaalisten ja interdiskursiivisten ilmiöiden analyysista. Kiitämme artikkelin nimettömiä arvioijia rakentavista kommenteista sekä tutkimusavustajana toiminutta Merja Nivalaa.

2. Kielipankissa saatavilla olevaa Suomi24-aineistoa ovat kuvanneet tarkemmin Lagus, Pantzar, Ruckenstein ja Ylisiurua (2016). 
aiotaan sietää sivistysmaissa?. ${ }^{3}$ Keskustelunavaukseen tuli muutaman päivän kuluessa kaiken kaikkiaan 39 vastausta, joista 13 on sittemmin poistettu sääntöjen vastaisina. Keskusteluketju valikoitui tutkimuksemme kohteeksi julkaisuajankohtanaan saamansa huomion vuoksi; se oli lokakuussa 2017 yksi Suomi24-yhteisöpalvelun etusivun nostoista, jota luettiin ja kommentoitiin runsaasti ja josta moderaattorit myös tekivät paljon poistoja. ${ }^{4}$ Analyysissamme tarkastelemme aineistossa esiintyviä kielellisiä ilmiötä ja niiden yhteyttä maahanmuuttovastaisen ideologian ja viestiketjun osanottajien identiteettien rakentumiseen. Huomiomme kohdistuu erityisesti siihen, millaisin kielellisin keinoin aineistossamme rakennetaan erilaisia ryhmäidentiteettejä ja näiden varaan rakentuvaa polarisaatiota "meidän" ja "heidän/niiden" välillä. Osoitamme, että ryhmäidentiteettien kielellisellä rakentamisella on aineistossamme yhteys syrjivään puheeseen, jollaiseksi ymmärrämme myös vihapuheen. Vihapuhetutkimuksen lisäksi tutkimuksemme liittyy maahanmuuttokeskustelujen tutkimukseen, jota on tehty paljon kriittisessä diskurssintutkimuksessa (ks. esim. Wodak \& van Dijk toim. 20oo; suomen osalta Lahti 2019; Herneaho 2018).

Metodologisesti tutkimuksemme on pitkälti perinteistä tekstianalyysia: olemme analysoineet koko viestiketjun morfologisesta, leksikaalisesta, syntaktisesta, tekstuaalisesta ja diskursiivisesta näkökulmasta ${ }^{5}$ ja valinneet käsittelyyn analyysissa tärkeimmiksi osoittautuneiden ilmiöiden joukosta toisteisimmat ja näkyvimmät. Lisäksi hyödynnämme kriittisen diskurssintutkimuksen sekä retoriikan ja argumentaation tutkimuksen metodologiaa tarkastellessamme analyysimme kohteena olevaa tekstiä osana sitä ympäröivää yhteiskuntaa.

Analyysimme on deskriptiivistä, ja siinä yhdistyvät myös kirjoittajien erilaiset teoriataustat, mikä näkyy muun muassa siinä, että lähestymme viestejä yhtäältä pragmaattisen perinteen pohjalta ja analysoimme, kuinka kielelliset ilmaukset saavat käyttökontekstissaan tietynlaisen tulkinnan. Toisaalta tarkastelemme viesteissä kriittisen sosiolingvistiikan (ks. Heller, Pietikäinen \& Pujolar toim. 2017) ja kriittisen diskurssintutkimuksen (ks. Pietikäinen 200o) perinteen mukaisesti myös sitä, kuinka kielen käytössä luodaan todellisuutta ja rakennetaan yhteyksiä ja eroavaisuuksia ihmisten välille. Monista kriittisen diskurssianalyysin piiriin kuuluvista tutkimuksista poiketen emme kuitenkaan pyri osoittamaan yhteiskunnallisia epäkohtia ja esittämään niihin parannusehdotuksia. Pidämme tosin tutkimuksemme kohdetta eli lisääntynyttä vihapuhetta sinänsä valitettavana ja huolestuttavana yhteiskunnallisena ilmiönä, jota haluamme analysoida osittain myös tästä syystä. Kielellisesti vihapuhe on monimutkainen ilmiö (ks. Assimakopoulos ym. toim. 2017; Paakkinen 2017; Tuomarla 2019), jota on hedelmällistä tarkastella tekemällä yksityiskohtainen laadullinen analyysi yhdestä keskusteluketjusta sen sijaan, että olisimme tehneet esimerkiksi erilaisia

3. Viestiketju on verkkoliitteessä.

4. Laguksen ym. (2016: 9) mukaan Suomi 24:n moderointi tapahtuu jälkikäteen pääasiassa kävijöiltä tulleiden poistopyyntöjen perusteella, joihin Allerin palveluksessa olevat moderaattorit reagoivat pääsääntöisesti 1-2 vuorokauden sisällä.

5. Tarkoitamme diskurssilla tiettyyn sosiaaliseen toimintaan liittyvää merkityksenantoa (ks. Pietikäinen \& Mäntynen 2009: 25). Tässä merkityksessä diskurssi voi viitata niin kielenkäytön kohteena olevaan ilmiöön (esim. maahanmuuttodiskurssi) kuin ilmiöön, jota diskurssissa rakennetaan (esim. identiteettidiskurssi). 
sanahakuja laajemmasta aineistosta. Yksityiskohtaisella ja moniulotteisella laadullisella analyysilla pyrimme kartoittamaan myös sanahakujen ulottumattomiin jäävän verkkovihapuheen kielellisten piirteiden moninaisuutta ja avaamaan tietä vihapuheen systemaattiselle kielitieteelliselle analyysille ja määrittelylle. Siten toivomme analyysimme osaltaan edistävän myös vihapuheen lisääntymisen ja normalisoitumisen vastaista taistelua.

Artikkelimme rakenne on seuraavanlainen: Luvussa 2 taustoitamme tutkimustamme ja esittelemme lyhyesti aiempia verkkovuorovaikutukseen keskittyneitä tutkimuksia. Luvut 3 ja 4 ovat analyysilukuja. Niissä lähtökohtana on tarkasteltavan viestiketjun tekstuaalinen monitasoisuus: jokainen viestiketjuun tuotettu yksittäinen viesti ${ }^{6}$ on yhtäältä oma tekstinsä, toisaalta osa laajempaa viestiketjun vuorovaikutuksellista kokonaisuutta, jota myös voidaan pitää sidosteisena tekstinä (ks. Halliday 1978: 61). Tämän vuoksi olemme jakaneet aineistossamme esiintyvät ilmiöt kahteen kategoriaan, tekstinsisäisiin (intratekstuaalisiin) ja tekstien ja diskurssien välisiin (intertekstuaalisiin ja -diskursiivisiin) ilmiöihin. Intratekstuaaliset ilmiöt, kuten nimeävät ja viittaavat ilmaukset, ovat huomiomme kohteena luvussa 3. Luvussa 4 taas tarkastelemme aineistossamme esiintyviä intertekstuaalisia ja interdiskursiivisia ilmiöitä, jotka liittävät viestiketjun osaksi laajempaa kontekstia. Luvussa 5 esitämme yhteenvedon, jossa kokoamme yhteen tavat, joilla aineistossamme rakennetaan maahanmuuttovastaista ideologiaa ja luodaan "me" vs. "ne" -vastakkainasettelua erilaisin leksikaalisin, syntaktisin, tekstuaalisin ja diskursiivisin keinoin, ja pohdimme analyysimme tuloksia.

\section{Verkkovuorovaikutuksen tutkimus}

Kielentutkimuksessa on tutkittu verkossa tapahtuvaa vuorovaikutusta ja viestintää 1980-luvun lopulta lähtien, ja tutkimussuuntauksia on useita. Tutkimuksessa on käsitelty muun muassa teknologisten ratkaisujen vaikutusta siihen, miten eri alustoilla viestitään ja kuinka yhteisöllisyyttä rakennetaan. Tietokonevälitteisen viestinnän tutkimuksen pioneeri Susan Herring (2004) esittää, että verkkovuorovaikutteisten ryhmien yhteisöllisyyttä voi hahmottaa kolmesta eri kulmasta, jotka ovat sosiaalisuus, tuen osoittaminen ja identiteetti. Yhteisön vuorovaikutus on keskiössä jokaisessa näistä osa-alueista, ja sitä voidaan tutkia kielentutkimuksen keinoin. Aktiivisimmat käyttäjät määrittävät pitkälle, mikä on palstan tai ryhmän identiteetti ja käyttäjien keskinäinen hierarkia. Vaikka yhden keskusteluketjun analyysi ei kerro laajemmin tietyn verkkoyhteisön rakenteesta, on verkkoyhteisöllisyyden rakentamisen näkökulma keskeinen myös tässä artikkelissa.

Suomenkielisiä verkkokeskusteluja on tarkasteltu muun muassa tunnepuheen, kokemusten jakamisen ja vertaistuen osoittamisen näkökulmasta (mm. Ketola 2013; Savolainen 2018; Virtanen 2018; Rosenberg 2018). Verkkokeskusteluja on myös analy-

6. Käytämme neutraalia termiä viesti eri osallistujien tähän keskusteluun tuottamista tekstikokonaisuuksista. Muita mahdollisia termivalintoja olisivat olleet $\mathrm{mm}$. kommentti tai puheenvuoro. 
soitu jonkin verran keskustelunanalyyttista menetelmää soveltamalla (esim. Virtanen \& Kääntä 2018). Retoriikan näkökulmasta verkkokeskusteluja lähestyy Lahti (2019), joka käsittelee väitöskirjassaan Suomi24-verkkofoorumin maahanmuuttoaiheisia keskusteluja. Lahti (mt.) hyödyntää tutkimuksessaan metodina diskurssintutkimusta, ja hänen tutkimuksensa liittyykin aineistoltaan ja metodeiltaan läheisesti tässä artikkelissa esiteltyyn tutkimukseen. Digitaalisen retoriikan tutkimusmetodeja ovat eritelleet myös Lehti ja Eronen-Valli (2018). Verkkovuorovaikutuksen kielellisiä piirteitä yleisluontoisesta näkökulmasta puolestaan on suomeksi esitelty Helasvuon, Johanssonin ja Tanskasen (2014) toimittamassa teoksessa Kieli verkossa: Näkökulmia digitaaliseen vuorovaikutukseen, jossa tutkimusaineistoina on käytetty muun muassa blogikirjoituksia, verkkokeskusteluja, verkkouutisia ja yritysten verkkosivuja.

Suomi24-aineiston tuleminen osaksi Kielipankkia vuonna 2015 on innoittanut tutkijoita tarkastelemaan verkkokeskusteluja: Helsingin yliopiston Kansakunnan mielenliikkeet -tutkijakollektiivin parissa on tutkittu suomalaista verkkokeskustelua erityisesti yhteiskunnallisten ilmiöiden ja trendien syntymekanismien näkökulmasta (https://blogs.helsinki.fi/citizenmindscapes/). Jantunen (2018) on puolestaan analysoinut seksuaalivähemmistöihin liittyviä diskursseja Suomi24-aineistossa. Kielentutkimuksessa Suomi24:n kaltaisten suurten aineistojen analyysissa pyritään nykyään usein yhdistämään korpustutkimuksen menetelmiä diskurssianalyysin laadulliseen tarkasteluun (mm. Jantunen 2018; Johansson, Jantunen, Heimo, Ahonen \& Laippala 2018).

Tämä tutkimus nivoutuu osaksi aiempaa verkkokeskustelujen tutkimusta. Lähestymistapamme tässä artikkelissa poikkeaa kuitenkin esimerkiksi aiemmista Suomi24-aineistosta tehdyistä kielellisistä analyyseista siten, että se pyrkii olemaan mahdollisimman moniulotteinen ja syväluotaava tutkimus suppeahkosta ${ }^{7}$ kokonaisuudesta (vrt. Virtanen \& Kääntä 2018). Uutta lähestymistavassamme on myös se, että tarkastelemme ilmiötä, joka vaikuttaa olevan nimenomaan verkkokeskustelulle tyypillinen: maahanmuuttovastainen vihapuheen tunnusmerkit täyttävä "huutelu" tuntuu olevan erityisesti internetin enemmän tai vähemmän anonyymeilla keskustelualustoilla leviävä ilmiö, eikä se sellaisenaan toteudu muualla yhteiskunnassa - ainakaan vielä. Tutkimuksemme tuo uutta tietoa verkossa tapahtuvan vihapuheen kielellisistä ja diskursiivista piirteistä; on mahdollista, että jotkin näistä piirteistä ovat tyypillisiä verkkovuorovaikutukselle ylipäätään, mutta se jääköön tulevan tutkimuksen osoitettavaksi.

\section{Intratekstuaalisia ilmiöitä: nimeäminen ja viittaaminen}

Tässä luvussa analysoimme, millaisia toimijoita viestiketjussa nimetään tai jätetään nimeämättä sekä kuinka kyseisiin toimijoihin viitataan ketjun edetessä. Alaluku 3.1 käsittelee toimijoiden eksplisiittistä nimeämistä ja nimeämisen keinoja. Alaluvussa 3.2 analysoimme, millaisia referentiaalisia ketjuja muodostuu toimijoita nimeävien ja heihin

7. Aineistona käyttämässämme keskustelussa on 848 sanaa; merkkimäärä on välilyönteineen 6901. 
viittaavien ilmausten ympärille. Alaluvussa 3.3 taas kuvaamme tapoja, joilla erilaisiin toimijoihin voidaan aineistossamme viitata heitä eksplisiittisesti nimeämättä.

\subsection{Eksplisiittisesti nimetyt toimijat}

Nimeäminen palvelee muun muassa kategorisointia ja on keskeinen keino joko etäännyttää tai lähentää keskustelunalainen kohde itsestä tai arvioida kohdetta (ks. Määttä 2004: 332-333). Aineistossamme nimeäminen koskee ennen kaikkea ulkoryhmää eli keskustelun osanottajista erillistä joukkoa ja palvelee näin toiseuttamista. Aineistossa on erotettavissa kolme nimeämisen pääluokkaa: viestien sisällä tapahtuva 1) neutraali ja 2) affektiivinen nimeäminen (mukaan lukien uudissanat) sekä 3) nimimerkit, joilla viestien tuottajat monissa tapauksissa tuovat julki eetoksensa ja asemoivat oman viestinsä osaksi keskusteluketjua.

Neutraalia nimeämistä edustavat ilmaukset ovat useimmiten substantiivilausekkeita (NP), jotka eivät itsessään sisällä eksplisiittisen affektiivista ainesta, mistä johtuu käyttämämme nimitys neutraali. Tähän kategoriaan kuuluu ilmauksia, joilla keskustelun osanottajat voivat yhtäältä viitata itsestään erillisiin ryhmiin (esim. vierasmaalaiset, muslimit, tulijat ja vieraiden maiden kansalaiset), tai toisaalta sellaisiin ryhmiin, joihin heidän ainakin periaatteessa voi olettaa kuuluvan (esim. kansa, kantaväestö). Vaikka tähän ryhmään kuuluvat ilmaukset ovat periaatteessa neutraaleja, niiden käyttökontekstit osoittavat asennoitumista. Tätä havainnollistaa esimerkki 1, jossa esiintyy NP vierasmaalaiset. Vaikka puheenalaisena oleva referenttijoukko on esimerkissä nimetty näennäisen neutraalisti, heidät eli vierasmaalaiset erotetaan kuitenkin omaksi yhtenäiseksi ryhmäkseen, joka ehdotetaan poistettavaksi täältä eli Suomesta sillä perusteella, että Suomi kuuluisi vain valtaväestölle (vrt. Herneaho 2018: 208-211):

(1) ggse

2.10.2017 7:11

En hyväksy minäkään. Jos eivät vierasmaalaiset osaa elää Suomessa kunnolla, niin heidät on poistettava täältä. (viesti $8^{8}$ )

Substantiivi vierasmaalaiset on periaatteessa neutraali, koska sen referentiaaliseen perusmerkitykseen ei liity erityistä negatiivista tai positiivista konnotaatiota. Toisaalta yhteiskunnassa stigmatisoituneisiin, erityisesti ihmistarkoitteisiin viittaavat sanat muuttuvat konnotaatioltaan vääjäämättä jossakin määrin negatiivissävytteisiksi, kun ne ovat toistuneet tarpeeksi monta kertaa negatiivisissa konteksteissa. Kontekstiin liittyvien negatiivisten vivahteiden voi siten katsoa tarttuvan myös kielelliseen ainekseen, jolla tarkoitteeseen viitataan. Ulkomaalaisia tarkoittavissa sanoissa negatiivistumisen siemen on usein jo sanojen perusmerkityksessä, jonka sisään on rakentunut toiseuden korostaminen. Siten esimerkiksi ulkomaalainen viittaa sisäryhmän ulkopuolella olevaan, vierasmaalainen taas kotimaan kannalta vieraaseen ja outoon. (Ks. sisä- ja ulkoryhmäkategorisaation kielellisestä rakentumisesta Pälli 2003.)

8. Esimerkkien loppuun on merkitty, kuinka mones keskusteluketjun viesti on kyseessä. 
Saattaa olla, että neutraaleilla, asiatyylisillä nimityksillä tavoitellaan aineistossamme argumentatiivista vakuuttavuutta ja uskottavaa eetosta, jota olisi vaikeampi saavuttaa tunnepitoisella huutelemisella. Myös moderoinnin näkökulmasta asiatyyli on varmempi valinta, sillä ilmausten näennäinen neutraalius estää moderaattoria poistamasta viestejä, vaikka viestin kokonaissisältö olisikin vihamielinen, kuten seuraavassa esimerkissä:

\section{(2) Tervemenoatakaisin}

4.10.2017 11:51

En tiedä miten suurta osaa kansasta edustan, mutta minä en siedä muslimeja lainkaan, en maltillista enkä radikaalia. Puolestani ne kaikki saisi pakata ensimäiseen rahtilaivaan ja kuskata ruumassa lähiitään. (viesti 25)

Esimerkeissä 1 ja 2 esitetyn kaltaiset näennäisen neutraalisti tietyn ihmisryhmän nimeävät ja näin siihen viittaavat ilmaukset ovat tyypillisesti monikollisia yleistäviä substantiivilausekkeita, joilla keskustelun osanottaja kuvaa geneeristä joukkoa (vrt. Herneaho 2018: 210); kontekstissaan niitä käytetään luonnehtimaan tiettyä joukkoa yleisellä tasolla ja kuvaamaan sen taipumuksia (ks. VISK $\$ 1408$ ). Monikollisilla substantiivilausekkeilla rakennetaan aineistossamme toiseutettua ulkoryhmää, jonka vastakohtana mainitaan joissakin viesteissä yhtä lailla yleistävät, kollektiiviset substantiivilausekkeet kantaväestö tai kansa (vrt. Lahti 2019: 120-122; Johansson ym. 2018: 108). Viestin kirjoittajan voidaan joskus nähdä edustavan "kansan ääntä", toisinaan hän taas haluaa erottautua typeränä esitetystä kansasta (vrt. Johansson ym. 2018: 105-106). Seuraava asiatyylinen esimerkki 3 havainnollistaa substantiivilausekkeiden kansa ja kantaväestö käyttöä aineistossamme. Esimerkistä käy ilmi se, kuinka näitä ilmauksia käytetään kuvaamaan ulkoryhmälle (esim. vierasmaalaiset, ulkomaalaiset) vastakkaista sisäryhmää eli "meitä" (ks. myös Lahti 2019: 122):

(3) qåaäzm

3.10.2017 15:40

Toivottavasti olen väärässä, mutta pahoin pelkään kantaväestön vain turtuvan tilanteeseen, kunhan asia ei tule lähelle. Mikään ei tule muuttumaan ellei riittävän moni koe terrorismia lähipiirissään, tai itseensä kohdistuen. Kansa pelkää jo nyt nousta vastarintaan, osin työpaikan menettämisen pelossa, eikä tee nyt muuta kuin purisee omissa oloissaan, sekä pui korkeintaan nyrkkiä. Mikä käsittämättömintä, asiasta huolestuneetkin äänestävät aina ja ikuisesti juuri ne samat maanpetturit eduskuntaan, jotka jatkavat maan tuhoa. Muuta ei tapahdu, ja tämän saa havaita noiden isänmaallisten mielenosoitusten vähäisenä väkimääränä. Kaksi vuotta on pidetty miekkareita, eikä väkimäärä ole noussut tuhansiin kuten pitäisi olla. Muutama kymmenen korkeintaan mukana näissä. En tiedä kuinka monta uhria pitää tulla, että kansa valtavin joukoin lähtisi barrikadeille. Täytyy tulla totaalinen katastrofi jolloin ei enää ole mitään menetettävää kenelläkään, ja silloin korkeintaan he voivat nousta vastarintaan. (viesti 19) 
Esimerkissä 3 kirjoittaja erottaa itsensä kantaväestöstä ja kansasta, jotka hän kuvaa passiivisina uhreina (vrt. Johansson ym. 2018: 106-109). Tämä näkyy myös siinä, että kirjoittaja viittaa itseensä ja omaan toimintaansa yksikön 1. persoonalla (olen väärässä, pahoin pelkään, en tiedä), mikä rakentaa erottelua minä-kirjoittajan ja "muun kansan" välille.

"Meidän" eli kansan ja "muiden" eli ulko- tai vierasmaalaisten lisäksi viesteissä esiintyy myös näiden välille asettuva ryhmä: poliitikot ja yhteiskunnallisen vallan edustajat (vrt. Lahti 2019: 127). Yhtäl̈lä heidät erotetaan kansan joukosta omaksi ryhmäkseen, jota voidaan myös kovin sanoin arvostella, toisaalta he esiintyvät osana Suomea ja ovat sen edustajia. Poliitikot ja yhteiskunnallisen vallan edustajat mainitaan keskustelussa ihmisryhmänä (poliitikot, päättäjät, ministerit, valtionjohdot) mutta myös nimettyinä yksilöinä (Sipilä, Orpo, Merkel, Putkonen ja de Wit). Yhteiskunnallisten vaikuttajien nimien mainitseminen on myös osa nettikeskustelijan identiteetin ja kielellisen auktoriteetin rakentamista, sillä kirjoittaja ilmentää niiden kautta omaa tietämystään ajankohtaisesta politiikasta. Äärimmillään ero kansan ja naiivien poliitikkojen välillä näyttäytyy väkivaltaan kiihottamisena: jos se ei valtionjohdoille sovi, niin sitten mestataan poliittiset päättäjätkin (viesti 1), Ampukaaittenneministerit (viestin 10 kirjoittajan nimimerkki).

Lisäksi monissa viesteissä yksilöidään juuri uutisissa olleita terroristeja: Pariisin akbar-hyökkääjä (viesti 10), Marseillen puukottaja (viesti 8). Kuten poliitikkojen nimeltä kutsuminen osoittavat nämäkin nimeämiset nettiviestijän seuraavan aktiivisesti ajankohtaisia tapahtumia. Ajankohtaisten uutisten jälkiä analysoimme tarkemmin alaluvussa 4.1.

Vaikka vihapuhe mielletään usein tunnepitoiseksi puheeksi, syrjivä puhe ei välttämättä ole eksplisiittisen affektiivista. Esimerkiksi Vitikan (2014) analysoiman kolmen oikeuteen päätyneen vihapuhetapauksen perusteella vihapuhe voi koostua tunnusmerkittömistä, näennäisesti objektiivisista väitelauseista, joissa ei tuoda kielellisesti esiin, kenen näkökulmasta tai mielipiteestä on kysymys. Samantyyppisiä havaintoja esittää maahanmuuttodiskursseja eduskuntapuolueiden vaalimateriaaleissa tarkastellut Herneaho (2018: 214), jonka mukaan kielteistä kuvaa maahanmuuttajista luodaan usein epäsuorasti. Tällaista kielenkäyttöä voidaan pitää vihapuheena siinä mielessä, että se on syrjivää, vaikka siinä ei välttämättä suoraan uhata ketään.

Näennäinen objektiivisuus näkyy myös edellä käsitellyissä sinänsä neutraaleissa henkilöviittauksissa. Selvästi affektiivisia henkilöviittauksia viestiketjussa on yllättävän vähän. Niitä ovat lähinnä suhteellisen uudet sanat, jotka ovat ylipäätään melko tavallisia verkkokeskustelujen henkilöviittauksissa. Usein uusien sanojen käyttämisen tavoitteena on osoittaa kielellistä nokkeluutta, joka on verkkokirjoittelussa arvostettua, sillä kekseliäs kielenkäyttö saa kirjoittajan erottumaan joukosta ja kerää hänen viestilleen tykkäyksiä. Suomi24-foorumilla onkin keksitty uudissanoja, jotka joissain tapauksissa (esim. perpanssi, ks. Tuomarla 2016) ovat ensin levinneet foorumilla ja myöhemmin myös foorumin ulkopuoliseen käyttöön. Aineistossamme uudissanat viittaavat usein poliittiseen tai ideologiseen kantaan ja osoittavat henkilön affektisesti latautunutta asennoitumista: suvakit (3 esiintymää viestissä 14), persut (viesti 17), kokkareet ja vassarit (viesti 24). 
Uudissanoista omintakeisin on viestissä 12 esiintyvä mussu merkityksessä 'muslimi'. Se on kiinnostavalla tavalla samanaikaisesti ulkoisesti hellittelysanan kaltainen (ks. KS s.v. mussukka), mutta aineistossamme se on käytössä negatiivisessa merkitysyhteydessä: mikäköhän sota syttys, jos me tehtäs mussuille samat teot mitä he ovat meille tehneet (ks. esim. 12 alaluvussa 4.1).

Aineistossa on lisäksi paljon sellaisia viestejä, joissa kirjoittajat ilmentävät halveksuntaansa avoimen negatiivisilla sanavalinnoilla: meidän mätäsisuksisia ministereitämme (viesti 10), kuppaiset valepukit (viesti 11, viittaa muslimeihin) ja sysineekerit (viesti 23, nimimerkki). Epäsuorasti negatiivisia ovat ironiset ilmaukset, kuten teillä arvon päättäjillä (viesti 4) ja moderaattorin oletettuun muslimimyönteisyyteen viittaava nigab-mode (sic, viesti 16). Halveksuntaa voidaan osoittaa myös muuttamalla jo suhteellisen vakiintuneen uudissanan muotoa kuten viestissä 14, jossa suvakit on kirjoitettu muotoon syvakit. Kyseessä voi olla näppäilyvirhe, mutta mikäli kirjoitusasu on harkittu valinta, sillä viitattaneen siihen, että suvakkien ajattelu on "syvältä" eli alaarvoista (ks. KS s.v. syvällä).

Viestien sisällä tapahtuvan nimeämisen lisäksi kirjoittajien itse itselleen keksimät nimimerkit eli käyttäjänimet ovat huomionarvoinen seikka verkkokeskustelussa. Nimimerkkien avulla kirjoittajat ensinnäkin luovat itselleen yksilöllisen ja yksilöivän tunnuksen, joka erottaa heidät muista osanottajista (Hämäläinen 2019). Toiseksi nimimerkkejä voidaan käyttää myös yhtenä keinona välittää puhujan ajatuksia tai mielipiteitä, sillä nimimerkki viittaa aina viestijään itseensä ja luo hänen toimijuuttaan. Tässä mielessä nimimerkkiä voidaan pitää persoonapronominien tapaan tietynlaisena kielellisesti performatiivisena ilmauksena (vrt. Benveniste 1971 [1966]), jolla kirjoittajat tuovat näkyviin eetoksensa. Kolmanneksi nimimerkillä voidaan osoittaa viestin liittyvän edelliseen viestiin tai nivoa se osaksi koko aiemmin kirjoitettujen viestien muodostamaa tekstikokonaisuutta.

Monet aineistomme nimimerkeistä vaikuttavat sattumanvaraisilta kirjain- ja numeroyhdistelmiltä, kuten ggse (viesti 8), rtggtgrgvrf (viesti 24), i5i56i (viesti 26) tai qåaäsm (viesti 18), tai sitten ne päinvastoin nivoutuvat selvästi osaksi viestin sanomaa, kuten tapauksissa verileikki (viesti 4) ja Ampukaaittenneministerit (viesti 10). Sattumanvaraisen oloinen kirjain- tai numeroyhdistelmä nimimerkkinä voi viitata siihen, ettei nimimerkille haluta laittaa painoarvoa, tai sillä voidaan pyrkiä osoittamaan, että kyseessä on vain alustan vaatima tekninen toimenpide ennen varsinaista viestiä. Ei kuitenkaan ole poissuljettu vaihtoehto, etteikö "siansaksaa" muistuttava nimimerkki (esim. qåä̈sm) olisi jollain tavalla osa toiseuttamista ja ilmaisisi siten myös asennoitumista puheenalaiseen ulkoryhmään. Tapauksissa, joissa nimimerkki puolestaan on selvästi osa viestin sanomaa, se tyypillisesti vahvistaa sitä samaan tapaan kuin otsikko uutistekstissä. Esimerkiksi viestiketjun aloittajan nimimerkki on henkilöysässä, jolla hän antaa esimakua muslimien maahanmuuttoon liittyviä uhkakuvia maalailevan viestinsä väkivaltaisesta lopetuksesta. Toisinaan nimimerkki voi myös luokitella viestin kirjoittajaa ja näin ilmentää hänen kantaansa käsiteltävään aiheeseen: tällainen on nimimerkki antimatu1 ${ }^{9}$ (viesti 3).

9. Matu tulee sanasta maahantunkeutuja, ja MV-lehti otti sen käyttöönsä vuonna 2015 (ks. https:// fi.wiktionary.org/wiki/matu). 
Nimimerkit voivat myös toimia metatason kommentteina meneillään olevaan keskusteluun. Tätä havainnollistaa esimerkki 4, jossa nimimerkki vilpitönkysymys on mahdollista tulkita metakielelliseksi kuvaukseksi siitä, mikä viestissä esitetyn kysymyksen tarkoitusperä ja sävy on:

(4) vilpitönkysymys

3.10.2017 20:41

Kuuluuko islam muka sivistysvaltioihin? (viesti 22)

Viestiosan kysymyksessä esiintyvä partikkeli muka on kuitenkin ristiriidassa nimimerkin esittämän kysymyksen vilpittömyyden kanssa. Muka antaa tässä kontekstissa vahvan vihjeen viestin kirjoittajan omasta mielipiteestä: se osoittaa, että hän suhtautuu epäillen esitetyn asiaintilan paikkansapitävyyteen (ks. VISK $\$ 1495$ ). Presuppositio on, että kysymykseen oletetaan annettavan kielteinen vastaus, joka seuraavan kommentoijan viestissä (viesti 23) tuotetaankin: No ei, ei todellakaan kuulu. Kuuluu vain ja ainoastaan pimeimpään Afrikkaan. ${ }^{10}$

\subsection{Referentiaaliset ketjut}

Nimeäminen palvelee ryhmien ja kirjoittajan oman identiteetin näkyväksi tekemistä: viittauksen avulla toimija voidaan tuoda osaksi viestiketjun maailmaa, millä puolestaan on tyypillisesti kirjoittajan argumentaatiota tukeva funktio. Aineistossamme samankaltaiset nimeävät viittaukset toistuvat useiden eri kirjoittajien viesteissä, ja kirjoittajat hyödyntävät muiden kirjoittajien keskusteluun tuomia nimeäviä ilmaisuja. Tässä alaluvussa tarkastelemme nimeävien ja viittaavien ilmausten ketjuuntumista.

Aineistomme kirjoittajien mielipiteet ovat melko samankaltaisia, ja viestiketjussa rakennetaankin yhteistä viholliskuvaa maahanmuuttajista. Ketjussa on vain yksi viesti, jossa selvästi asetutaan puolustamaan ulkomaalaisia tai muslimeja, joihin viitataan pronomineilla ne ja he:

(5) antimatu1

1.10.2017 20:28

$\mathrm{Ne}$ ovat tulleet jäädäkseen, kun on tänne otettu. On vain opeteltava tulemaan heidän kanssaan toimeen parhaan mukaan. (viesti 3)

Vaikka esimerkki 5 poikkeaa sanomaltaan muista ketjun viesteistä (ja on mahdollisesti niin sanottu trollaus eli viesti, jonka on tarkoitus tahallaan häiritä käytävää keskustelua), se havainnollistaa sitä, kuinka toimijoihin viitataan aineistossamme usein suoran nimeämisen sijaan pronomineilla. Lisäksi se on esimerkki tälle viestiketjulle tyypilli-

10. Tällaiset vierusparin (esim. kysymys-vastaus) muodostavat rakenteet, jotka rakentuvat perättäisissä viesteissä viestiketjun sisällä, ovat merkki siitä, että viestiketjun sisäinen koheesio on suuri. Verkkokeskustelussa ei nimittäin ole tavatonta, ettei perättäinen vuoro liity mitenkään edelliseen (tai edeltäviin) viesteihin (mm. Kleinke 2010). 
sestä tavasta jatkaa nimettyjen tarkoitteiden käsittelyä seuraavissa viesteissä. Tällaisissa tapauksissa, joissa puheenaihe jatkuu lausumasta toiseen, siihen viittaavista kohosteisista substantiivilausekkeista muodostuu referentiaalisia ketjuja (ks. Tiainen 1998; VISK $\$ 1443)$.

Hyvä esimerkki tietyn kielellisen ilmauksen ympärille rakentuvasta referentiaalisesta ketjusta on tarkastelemamme viestiketjun aloitusviestissä esitelty ilmaus muslimit. Viestiketjun aloittaa nimimerkki henkilöysässä otsikolla Kauanko muslimeja aiotaan sietää sivistysmaissa?." Aloitusviestin ja samalla koko keskustelun otsikolla on viestiketjun rakentumisen kannalta sikäli merkittävä rooli, että se määrittelee topiikin, johon muut keskustelun osanottajat vastausvuoroissaan palaavat (Arendholz 2013).

Aloitusviestin aiheeseen palaaminen johtaa siihen, että tietyn topikaalisen NP:n ympärille syntyy referentiaalista jatkuvuutta ja viittausketjuja (ks. Givón 1983), kun samaan tarkoitteeseen palataan ja siihen viitataan viestiketjun edetessä. Referentiaalisten lausekkeiden ketjun tyypillinen lähtökohta on se, että ensimainintana on leksikaalinen NP ja uudelleenmainintana joko pelkkä pronomini tai pronominitarkenteinen NP (VISK $\$ 1443$ ). Kun ensimainintana ollutta substantiivilauseketta ei toisteta referentiaalisessa ketjussa, voidaan puhua anaforisista ilmauksista (ks. Fox 1987; ks. myös VISK $\$ 1405)$. Anaforisten ilmausten käyttö palvelee puheenaiheen jatkuvuutta, mikä näyttää tässäkin aineistossa olevan tyypillinen syy sille, miksi referentiaalisia ketjuja muodostuu.

Ensimmäisen kerran otsikossa mainittuun tarkoitejoukkoon (muslimeja) palataan jo otsikon kirjoittajan omassa aloitusviestissä (esim. 6). Esimerkissä on kursivoitu sellaiset kielelliset ilmaukset ja rakenteet, joiden voidaan anaforisesti katsoa viittaavaan samaan tarkoitteeseen kuin otsikon ilmaus muslimeja.

(6) henkilöysässä

1.10.2017 17:04

Lähes päivittäin saa kuulla allahu akbar-uutisia. Lapsivaimot, muiden uskontojen vainoamiset, tyttöjen sukuelimen silpomiset, naisten alistaminen jne jne jne. Raiskaukset, silmitön väkivalta uskonnon varjolla. Ei tällaista ole tilauksessa länsimaihin. Jos ei eletä niinkuin soveliasta on, niin sitten niskaperseotteella takaisin omiin sikolätteihinsä mistä ovat tulleet.

Nykymeiningillä alkavat taatusti pakkopalautukset kansalaisten toimesta ja jos se ei valtiojohdoille sovi, niin sitten mestataan poliittiset päättäjätkin. (viesti 1)

Tässä esimerkissä on huomionarvoista, että otsikossa mainittu tarkoitejoukko aktivoidaan viittauksen kohteeksi ensin melko implisiittisesti. Tähän otsikossa mainittuun korrelaattiin palataan viestin keskivaiheilla passiivin preesensin kieltomuodolla ehtolauseessa Jos ei eletä niinkuin soveliasta on. ${ }^{12}$ Sitä seuraa yhdyslause, jossa esitellään ne

11. Suomi24-foorumilla aloittaja otsikoi itse oman aloitusviestinsä.

12. Katsomme, että tässä yhteydessä passiivin käyttö tukee sitä seuraavien ilmausten anaforista tulkintaa. Käsittelemme passiivimuodon käyttöä aineistossamme laajemmin alaluvussa 3.3. 
seuraukset, joita mainitun ehdon toteutumisella on (niin sitten niskaperseotteella takaisin omiin sikolätteihinsä mistä ovat tulleet). Tässä yhteydessä esiintyy kaksi anaforista ilmausta: ensin monikon 3. persoonan possessiivisuffiksi -nsä (omiin sikolätteihinsä) ja sen jälkeen relatiivilauseessa ilmisubjektiton tulla-verbin monikon 3. persoonan perfektin liittomuoto ovat tulleet. Tässä verbimuodossa on kyse niin sanotusta nollaanaforasta eli tapauksesta, jossa edellä mainittuun tarkoitteeseen ei viitata uudestaan millään ilmikeinolla, vaan uudelleenmaininnan paikka jätetään tyhjäksi (Hakulinen \& Laitinen 2008: 162). Esimerkissä mainitulle $n s \ddot{a}$-possessiivisuffiksille ja ovat tulleet -verbimuodolle voidaan etsiä korrelaattia yhtäältä edeltävästä syntaktisesta kontekstista, toisaalta laajemmin ympäröivästä tekstikontekstista. Syntaktisen kontekstin perusteella korrelaatiksi tuntuu määrittyvän edeltävässä passiivilauseessa implikoitujen tarkoitteiden joukko, laajemmassa tekstikontekstissa taas otsikossa mainittu geneerinen tarkoitteiden joukko muslimit. Nämä tulkinnat voidaan kuitenkin yhdistää, sillä passiivilauseella kuvatun toiminnan voi tässä tapauksessa diskursiivisin perustein katsoa kuvaavan otsikossa mainitun ryhmän toimintaa. Anaforiseksi voidaan tulkita myös esimerkin 6 viimeisen kappaleen ilmaus pakkopalautukset, joka viittaisi tällöin otsikossa mainittuun referenttijoukkoon kohdistuvaan toimintaan (ø:n pakkopalautukset).

Myös aloitusviestiä seuraavissa, muiden kirjoittajien kirjoittamissa viesteissä kuljetetaan mukana otsikossa mainittua toimijoiden joukkoa. Tätä havainnollistaa esimerkki $7^{13}$. Anaforiset, substantiivilausekkeeseen muslimeja viittaavat ilmaukset on tässäkin esimerkissä kursivoitu ja nolla-anafora merkitty ø:lla:

(7) antimatu1

$1.10 .201720: 28$

Ne ovat tulleet jäädäkseen, kun $\emptyset$ on tänne otettu. On vain opeteltava tulemaan heidän kanssaan toimeen parhaan mukaan. (viesti 3)

Esimerkissä esiintyvien anaforisten pro-sanojen ( $n e, h e)$ lisäksi otsikon muslimejailmausta voidaan kuljettaa viestiketjussa mukana myös sen kanssa samaviitteisiä ilmauksia käyttämällä. Ainakin osin samaviitteisiksi voidaan katsoa edellisessäkin alaluvussa mainitut näennäisen neutraalit NP:t vierasmaalaiset ja vieraiden maiden kansalaiset sekä affektiivisemmat kuppaiset valepukit ja mussut sekä niiden yhteydessä esiintyvät persoonapronominit (ks. esim. 1, 11). Topiikin jatkuvuuden kannalta myös näiden ilmausten voidaan nähdä viittaavaan otsikossa ja aloitusviestissä esitettyyn geneeriseen tarkoitejoukkoon, joskin modifioivan siitä tehtäviä tulkintoja.

Referentiaalisella ketjuttamisella on aineistossamme puhujia yhdistävä ja heidän sisäryhmäidentiteettiään vahvistava funktio: viestiketjun sisäiset - sekä yksittäisten viestien sisäiset että niiden väliset - referentiaaliset ketjut vahvistavat vaikutelmaa siitä, että keskusteluun osallistuvien uusien kirjoittajien käsitys maailmasta on yhdenmukainen edeltävien kirjoittajien kanssa eikä referenttejä tarvitse tämän vuoksi aina toistaa tai eksplikoida. ${ }^{14}$ Mitä enemmän osallistujien oletetaan olevan yksimielisiä kä-

13. Esimerkkivirke 7 oli jo aiemmin esillä esimerkissä 5 .

14. Anaforisten ilmausten käyttäminen voi myös olla tyypillistä verkkovuorovaikutukselle yli- 
siteltävästä aiheesta, sitä vähemmän on tarvetta selittää ideologista kehystä: on siis yhtäl̈ltä "me", jotka tietävät, keistä puhutaan, toisaalta taas "ne", joista puhutaan ja jotka eivät kuulu sisäryhmään. Tämä havainnollistuukin erityisen hyvin seuraavassa esimerkissä, joka on aineistomme viimeinen moderaattorin sallima viesti. Siinä kirjoittaja asettaa vastakkain monikon 1. persoonan pronominilla me konstruoidun sisäryhmän ja sen tavat (meidän tavat) sekä nolla-anaforalla ilmaistun ulkoryhmän (merkitty ø:lla), jonka pitää poistua, jos sopeutuminen ei onnistu:

(8) Järjenkäyttöonsallittuaa

4.10.2017 23:49

Maassa maan tavalla. Ei mulla muuta.

Jos meidän tavat ei sovi ø:lle, niin ø poistuu maasta vaan pois. (viesti 27)

Puheenalaisen kohteen nimeämättä jättäminen ja suoran viittauksen välttäminen on kiintoisa strategia, sillä tekstikoheesiota kasvattavan luonteensa ohella se kenties myös vihjaa siitä, että kirjoittajan sanavalinta rikkoisi foorumin sääntöjä. Lukija voi kuitenkin mielessään kuvitella, mitä nämä sanavalinnat olisivat - aukkoihin voi lukea sanavalintoja, joita kirjoittaja ei ole tehnyt. Täydentäminen vahvistaa vaikutelmaa sisäryhmään kuulumisesta, sillä argumentaation voima tulee myös siitä, mitä ei sanota ääneen vaan jätetään pääteltäväksi (Amossy 2016: 190). Diskurssinkin voidaan katsoa muodostuvan paitsi siitä, mitä sanotaan ja kirjoitetaan, myös sanomatta jättämisestä (Foucault 2014: 152).

Koska anaforisten ilmausten käyttäminen ja viittausten ketjuttaminen tapahtuvat kontekstuaalisesti kielenkäyttötilanteen asettamissa rajoissa, niiden avulla alleviivataan puheenaihetta keskustelijoiden yhteisen huomion - ja tässä tapauksessa myös huolen kohteena. Lisäksi korostetaan sitä, että kaikilla osanottajilla on aiheeseen jossain määrin yhtäläinen ja jaettu pääsy. (Vrt. Givón 1983; Ariel 1990; ks. myös Hakulinen \& Laitinen 2008: 162; VISK $\$$ 1444.) Kaikkien viestiketjun osanottajien on siis viittaukset ymmärtääkseen kyettävä identifioimaan puheena olevat referentit, mikä puolestaan edellyttää keskustelun osanottajilta yhteisymmärrystä mahdollisista viittauskohteista (ks. Cornish 1999: 25). Käsittelemässämme viestiketjussa yhteisymmärrys voidaan nähdä suorastaan yksimielisyytenä: mitä enemmän oletetaan osallistujien olevan yksimielisiä käsiteltävästä aiheesta, sitä vähemmän on tarvetta selittää. Puhetilanteessa yhteisesti rakentuvalle referenttien tunnistettavuudelle perustuu myös tekijän avoimeksi jättävien rakenteiden käyttö, jota siirrymme käsittelemään seuraavaksi.

\subsection{Tekijän identiteetin avoimeksi jättävät rakenteet}

Kriittisessä diskurssianalyysissä on tutkittu paljon kieliopillisten rakennevalintojen ideologisuutta (Hart 2015: 326), sillä valinnoilla on merkittävä vaikutus siihen, millai-

päätään: ne säästävät kirjoittajan aikaa ja vaivaa, kun näppäillään vain vuorovaikutuksen kulun kannalta välttämättömät merkit ja sanat. Tähän emme kuitenkaan pysty aineistomme pohjalta ottamaan tarkemmin kantaa. 
nen kuva jostakin tapahtumasta tai ilmiöstä syntyy. Viestiketjussa ilmenevä aukkoisuus ja elliptisyys on valinta, jonka tekevät mahdolliseksi tekstin sisäinen koherenssi ja viittaukset. Aineistomme pienuuteen nähden siinä esiintyy melko tiuhaan myös sellaisia kieliopillisia rakenteita, joissa tekijää tai puheenalaisena olevan toimijan identiteettiä ei ilmipanna eksplisiittisesti, toisin kuin esimerkiksi edellä alaluvussa 3.1 esitellyissä toimijan nimeävissä käytänteissä. Aineistossamme tällaisia tekijän avoimeksi jättäviä rakenteita ovat nollapersoona, passiivi ja muut passiivimaiset rakenteet, joiden avulla voidaan viitata inhimilliseen toimintaan ilman, että toimijaa koodaavaa subjektiargumenttia tarvitsee ilmipanna.

Nollapersoonaksi kutsutaan ilmiötä, jossa lauseesta puuttuu substantiivilauseke silloin, kun tarkoitetaan ketä tahansa ihmistä, johon sanottu soveltuu, myös - ja usein nimenomaan - puhujaa itseään tai puhuteltavaa. Nollapersoona on selvimmillään nollasubjektilauseissa eli lauseissa, joista puuttuu (ilmi)subjekti ja joissa verbi on yksikön 3. persoonassa, mutta nolla on mahdollinen myös muissa lauseasemissa. Nollasubjektilauseen oletettu subjekti ymmärretään henkilöviitteiseksi ja tarkoitteeltaan inhimilliseksi, kuitenkin siten, että nollapersoonan tarkoite on yksiköllinen, kun taas passiivi implikoi ensisijaisesti monikollista subjektia. ${ }^{15}$ (Laitinen 1995, 2006; VISK $\$ 1347$.

Tarkastelemassamme viestiketjussa nollapersoona esiintyy tyypillisesti konteksteissa, joissa kirjoittaja kuvaa omaa asennettaan tai mielipidettään, jonka hän ajattelee muiden voivan jakaa kanssaan. Tämäntyyppinen potentiaalinen jaettavuus onkin nollalauseille tyypillistä: Laitisen (1995: 344) mukaan nolla tarjoaa lausuman intensionaalisessa kehyksessä paikan, johon kuka tahansa voi halutessaan astua. Nollapersoonalauseita edustavat virkkeet 9a-c:

(9)

a. On vain opeteltava tulemaan heidän kanssaan toimeen parhaan mukaan. (viesti 3)

b. hyssyn, hyssyn. ei saa yleistää. yksittäistapaus. ei saa antaa pelolle valtaa. pitää kääntää molemmat posket. (viesti 12)

c. Muuta ei tapahdu, ja tämän saa havaita noiden isänmaallisten mielenosoitusten vähäisenä väkimääränä. (viesti 19)

Esimerkeissä kuvataan - nollarakenteille tyypillisesti - välttämätöntä ja subjektin itsensä kontrolloimattomissa olevaa toimintaa (vrt. Laitinen 1995: 340; ks. myös Varjo \& Suomalainen 2018). Esimerkissä 9a nolla esiintyy genetiivisubjektin saavassa nesessiivirakenteessa (ø:n on opeteltava), jonka avulla kirjoittaja tuo esiin välttämättömän toimintatavan epätoivotussa tilanteessa. Esimerkissä $9 \mathrm{~b}$ nollapersoona puolestaan esiintyy modaaliverbien saada ja pitää yhteydessä. Esiintymiskonteksti on ironinen: viestissään kirjoittaja kaiuttaa diskurssia, jolla maahanmuutosta hänen mielestään yhteiskunnassa puhutaan, ja toimintamahdollisuuksia, joita tässä diskurssissa esitetään yksit-

15. Nollapersoonan ja passiivin eroista kokoavasti ks. VISK \ 1363-1364; ks. myös Hakulinen \& Karlsson 1979: 254-255. 
täisille kansalaisille (ks. myös alalukua 4.1). Myös esimerkissä $9 \mathrm{c}$ nollapersoonalause rakentuu saada-modaaliverbin ympärille ( $ø$ saa havaita), jota käytetään siinä ilmaisemaan olosuhteista johtuvaa epätoivottua mahdollisuutta. Kaikki esimerkkivirkkeet 9a-c välittävät kirjoittajansa asennetta mutta siten, että kirjoittaja ei suoraan osoita kyseessä olevan hänen oma mielipiteensä; päinvastoin, asia esitetään pikemminkin yleisenä asiantilana, joka koskee ketä tahansa (ks. alalukua 4.2). Nollapersoonarakenteen käyttäminen palveleekin viestiketjussa puhujan argumentoinnin uskottavuutta mutta antaa samalla muille keskustelun osanottajille paikan samastua kulloisenkin kirjoittajan asenteeseen ja rakentaa tulevaa argumentointia samanlinjaiseksi.

Passiivia ja passiivimaisia rakenteit ${ }^{16}$ esiintyy aineistossamme erityisesti silloin, kun viestiketjun osanottajat kuvaavat toimintaa, jonka osaksi he eivät ainakaan suoranaisesti laske itseään. Usein tämä toiminta on sellaista, joka jollain tavalla liittyy vihapuheen kohteeseen. Esimerkkivirkkeet 10a-d havainnollistavat passiivin ja passiivimaisten rakenteiden käyttöä. Esimerkeissä 10a-b käytössä on (yksipersoonainen) passiivi: esimerkissä 1oa passiivin preesens (aiotaan), esimerkissä 1ob puolestaan passiivin perfekti (on otettu). Esimerkeissä 1oc-d kuvatun toiminnan subjektin taka-alaisuutta taas ilmaistaan deonttista modaalisuutta ilmaisevalla nesessiivisellä verbiliitolla (ks. VISK $\$ 1581$ ), joka muodostuu olla-verbistä ja siihen liittyneen verbin VA-partisiipin passiivimuodosta (on poistettava, on ajettava).

(10)

a. Kauanko muslimeja aiotaan sietää sivistysmaissa? (viesti 1, otsikko)

b. Ne ovat tulleet jäädäkseen, kun on tänne otettu. (viesti 3)

c. Jos eivät vierasmaalaiset osaa elää Suomessa kunnolla, niin heidät on poistettava täältä. (viesti 8 )

d. Nämä kuppaiset valepukit on ajettava ulos Euroopasta. (viesti 11)

Esimerkkejä 10a-d yhdistää se, että niissä jätetään mainitsematta, kenen toiminnasta on kysymys: kuka aikoo sietää tai on ottanut (a, b), kenen vastuulla on poistaa tai ajaa ulos (c, d)? ${ }^{17}$ Toimijan sijaan korostuu toiminnan kohde, joka on yllä olevissa esimerkkivirkkeissä pääosin sama: vihapuheen kohteena oleva ryhmä, josta käytetään tässä kontekstissa affektiivisuudeltaan ja spesifisyydeltään vaihtelevia mutta ainakin osin samanviitteisiä ilmaisuja muslimit, ne, vierasmaalaiset ja kuppaiset valepukit. Se, että toiminnan kohdetta ja siihen kohdistuvaa toimintaa korostetaan, palvelee vihapuheen funktiota tekstilajina (ks. Reisigl \& Wodak 2001: 58). Tällöin olennaista ei ole löytää konkreettisia ja toimivia ratkaisuja vaan lietsoa vihaa, pelkoa ja aggressiivisuutta tekstissä rakennettua ihmisryhmää kohtaan.

16. Suomen passiivin määritelmistä ks. tarkemmin Kelomäki 2019.

17. Toisinaan aineistossamme on mainittu jokin toimija(joukko), jonka vastuulle esitetty asiaintila sysätään ja jonka oletetaan voivan toimia tilanteen parantamiseksi. Usein nämäkin toimijaryhmät ovat kuitenkin melko geneerisiä. Esimerkiksi poliitikot mainitaan usein ryhmänä, jonka vastuuta asioiden ratkaisemiseksi peräänkuulutetaan. 


\section{Intertekstuaalisia ja interdiskursiivisia ilmiöitä}

Tässä luvussa siirrämme huomiomme intertekstuaalisiin suhteisiin, joita viestiketjulla ja siihen kuuluvilla yksittäisillä viesteillä on ulkopuolisiin teksteihin, konteksteihin ja diskursseihin. Sähköinen viestintä on korostetun intertekstuaalista, sillä siinä tekstit ja niiden osat siirtyvät kontekstista toiseen nopeasti.

Kielenainesten liikkumista kontekstista toiseen on totuttu kuvaamaan intertekstuaalisuuden käsitteellä, jonka Kristeva (1969) kehitti Bahtinin (1991) [1963 $]^{18}$ dialogisuuden käsitteen pohjalta. Intertekstuaalisuuden perusajatus on, että kaikki kielenkäyttö on yhteydessä muuhun kielenkäyttöön ja intertekstuaalisuuden tarkasteleminen on olennainen osa diskurssien analyysia. Tässä kirjoituksessa katsomme myös muiden henkilöiden puheen tai ajatusten referoinnin kuuluvan intertekstuaalisuuden piiriin.

Kriittiseen diskurssintutkimukseen kuuluu myös diskurssien välisten yhteyksien eli interdiskursiivisuuden tarkastelu. Keskeisenä ajatuksena on se, että diskurssit muokkaavat kielenkäytön kohteeksi tulevia aiheita ja niiden määritelmiä sekä diskurssiin kuuluvien lausumien olemassaolon ehtoja, rajoja ja keskinäisiä suhteita (Foucault 2005: 33-41). Käytännössä interdiskursiivisuus näkyy muun muassa genrejen sekoittumisena (Fairclough 1993: 138), mutta sitä osoittavat myös topokset eli argumentit tai teemat, jotka esitetään kielenkäyttäjäyhteisön yleisesti hyväksyminä totuuksina siten, ettei niitä tarvitse erikseen perustella (Anscombre 1995: 190). Kriittisessä diskurssintutkimuksessa topoksien on katsottu olevan olennainen osa erityisesti rasistisen ja muukalaisvihamielisen diskurssin rakentumista (Reisigl \& Wodak 2001), mutta tässä artikkelissa katsomme topoksien kuuluvan ideologian tasolle, eli ne ovat osa tekstissä ja diskurssissa aktivoituvia uskomuksia, näkemyksiä ja ajatusjärjestelmiä (vrt. Pietikäinen \& Mäntynen 2009: 58). Topos on pitkälti sama kuin tietyn kokonaisuuden tai ryhmän tyypillisestä edustajasta rakentunut kuvaus eli stereotypia, jossa kiteytyy kyseiseen kokonaisuuteen tai ryhmään liitetty mielipide, uskomus tai representaatio (Amossy \& Herschberg Pierrot 2014: 29, 34).

\subsection{Referointi}

Viestiketju on aloitettu 1. lokakuuta 2017, jolloin islamistimies surmasi kaksi nuorta naista teurastajanveitsellä Marseillen rautatieasemalla. Suomen ensimmäinen islamistinen isku oli tapahtunut 1,5 kuukautta aiemmin (18.8.2017), ja kaksi henkilöä sai tuolloin surmansa. Ylipäätään islamististen terrori-iskujen määrä Euroopassa kasvoi rajusti vuonna 2015 ja saavutti huippunsa vuonna 2017. Tätä taustaa vasten ei ole yllättävää, että viesteissä kaiutetaan ajankohdan uutisia.

Ajankohtaisten tapahtumien voidaan katsoa innoittaneen myös ketjun aloittajaa. Ensimmäisessä viestissä puhutaankin allahu akbar -uutisista, ja 10. viestissä akbarhyökkääjästä. Marseillen hyökkääjän tiedetään huutaneen kaksi kertaa lauseen Allahu akbar ('Jumala on suurin' tai 'Allah on suurempi' [WikiIslam 2019]). Esimerkiksi Ylen

18. Suppeampi laitos Проблемы Творчества Достоевского ('Dostojevskin luomistaiteen ongelmia') oli ilmestynyt Neuvostoliitossa jo 1929. 
verkkosivujen uutisessa 1.10.2017 (Pärssinen 2017) huuto mainitaan jo ingressissä, ja jutussa puhutaan myös hyökkääjään käyttämistä useista henkilöllisyyksistä, joista keskustellaan viesteissä 10 ja 15. Ylipäätään lause on tullut monelle länsimaalaiselle tutuksi nimenomaan terrorismin yhteydessä, vaikka se liittyy muslimeilla lähinnä rukoilemiseen ja on muun muassa osa rukouskutsua (Pye 1993, s.v. Allāhu akbar). Toisaalta lauseen käyttö sotahuudossa on perua jo profeetta Muhammedilta (Adamec 2009: 32). Aineistossamme lauseen käyttämisen taustalla voi olla paitsi halu välttää moderointia myös uhkakuvien maalaaminen. Samalla islamin harjoittamiseen olennaisena osana kuuluvan lauseen käyttäminen vain terrorismin yhteydessä rakentaa amalgaamista kuvaa (Angenot 1982: 127), jossa kaikki muslimit leimautuvat terroristeiksi.

Myös kotimaan uutisia referoidaan ketjussa runsaasti (esim. viesti 14). Joissakin tapauksissa (viestit 19 ja 18) referointi koskee kahden kirjoittajan välistä keskustelua, joka ei avaudu ulkopuolisille, ja joskus viitataan moderaattorin ajatuksiin (esim. viesti 16). Esimerkissä 11 taas mainitaan lähteeksi yhtäältä yleisesti jaettu järki ja toisaalta ulkomaalaislaki, jota kuitenkin referoidaan virheellisesti, sillä ulkomaalaislaissa ei kielletä ulkomaiden kansalaisten oleskelua Suomessa:

(11) i5i56i

4.10.2017 12:01

Vieraiden maiden kansalaiset on poistettava Suomesta oleilemasta. Niinhän sanoo jo oma ulkomaalaislakimmekin ja järki vielä sitäkin selvemmin! (viesti 26)

Ketjussa esiintyy jonkin verran myös kliseisten muoti-ilmausten ja vakiintuneiden sanontojen toistoa (esim. Menee ihon alle viestissä 7). Esimerkin 8 yhteydessä (alaluvussa 3.2) käsiteltiin referentiaalisen ketjun kannalta ilmausta Maassa maan tavalla. Ei mulla muuta. Siinä vakiintunut sanonta maassa maan tavalla yhdistyy suoraan lainaukseen valtiovarainministeri Alexander Stubbin tviitistä ${ }^{19}$ heinäkuussa 2015: "Monikulttuurisuus on rikkaus. Ei mulla muuta." Tässä lainaus siis asetetaan maahanmuuttokriittiseen kehykseen, jota ilmentävät paitsi sitä edeltävä vakiintunut sanonta myös viestijän nimimerkki Järjenkäyttöonsallittuaa.

Vakiintuneiden sanontojen luokkaan lienee laskettava myös uskonnollisten tekstien enemmän tai vähemmän sanatarkat lainaukset kuten seuraavassa esimerkissä, joka oli jo aiemmin esillä (esim. 9b):

(12) entätoisinpäin

2.10.2017 21:44

hyssyn, hyssyn. ei saa yleistää. yksittäistapaus. ei saa antaa pelolle valtaa. pitää kääntää molemmat posket. puukko kilahtaa, henki pellolle vilahtaa. mikähän sota syttys, jos me tehtäs mussuille samat teot, mitä he ovat meille tehneet. oltas narun jatkona lyhtypylväässä. (viesti 12)

19. https://twitter.com/alexstubb/status/625020379023675393 (23.4.2019). 
Esimerkin alussa referoidaan suoraan kuvitteellista puhetta, joka heijastaa suvaitsevaa ideologiaa ja voisi olla peräisin esimerkiksi uutisista, poliittisesta kielenkäytöstä tai suvakeiksi kutsutuilta suvaitsevuuden puolestapuhujilta (ks. KS s.v. suvakki). Ilmaisu hyssyn hyssyn merkitseekin tekstin alun lainaukseksi, josta kirjoittaja ei ole vastuussa ja joka ei vastaa hänen näkökulmaansa (Ducrot 1984), vaikka kirjoitus esiintyy hänen nimimerkkinsä alla. Tekstissä lihavoidut virkkeet taas ovat lainauksia uskonnollisista konteksteista. Ensimmäisessä (Raamattu 1992) referoidaan Jeesuksen vuorisaarnaa (Matt. 5:38-39: "Teille on opetettu: 'Silmä silmästä, hammas hampaasta.' Mutta minä sanon teille: älkää tehkö pahalle vastarintaa. Jos joku lyö sinua oikealle poskelle, käännä hänelle vasenkin.”). Seuraavassa virkkeessä taas lainataan vapaasti 1400-1500-luvuilla elänyttä saksalaista dominikaanimunkki Johann Tetzeliä, jonka nimiin luetaan anekauppaan liittyvä värssy "kun raha kirstuun kilahtaa, sielu taivaaseen vilahtaa". Nämä lainaukset niveltävät viestin kahteen osaan: siinä missä alku edustaa naiivia ja suvaitsevaista ideologiaa, viimeiset virkkeet heijastavat kirjoittajan omaa näkökulmaa ja maahanmuuttovastaista ideologiaa. Vastakkainasettelua korostaa tässä viestissä myös pronominein eksplikoitu ero meidän ja heidän välillä.

Raamattua (1992) siteerataan myös viestissä 9: silmä silmästä, kuten sanotaan. Hammurabin laista peräisin olevaa Vanhan Testamentin sääntöä "Älkää tunteko sääliä: henki hengestä, silmä silmästä, hammas hampaasta, käsi kädestä, jalka jalasta” (5. Moos. 19:21) pidetään hyvänä asiana, ja sillä perustellaan väkivaltaa oikeutettuna tekona.

Kristinuskoon liittyviä tekstejä referoivien viestien kirjoittajat näyttäisivät käyttävän lainaamiaan tekstifragmentteja kulttuurissa vakiintuneina sanontoina, joiden lainaamisella ja muokkaamisella osoitetaan kielellistä nokkeluutta. Toteamalla kuten sanotaan viestin 9 kirjoittaja tekee selväksi, että tekstifragmentti on hänen käsityksensä mukaan vakiintunut sanonta. Vaikka tekstifragmentteja siteerataan jopa alkuperäisen kontekstin kannalta päinvastaisella tavalla, niiden voidaan kuitenkin katsoa säilyttäneen konventionaalistumisesta kumpuavan voimansa ja ammentavan lisää voimaa uudesta kontekstistaan ja "väärästä" paikastaan uutisen yhteydessä. Derridan (1972: 365-393; ks. myös Rojola \& Laitinen 1998: 16-20) performatiivisuusteorian valossa referoinnin voima tulee tässä tapauksessa yhtältä fragmenttien toistamisen ja toistettavuuden aiheuttamasta konventionaalistumisesta ja rituaalistumisesta mutta toisaalta myös murrosvoimasta, jonka lähteenä on lausuman joutuminen uuteen kontekstiin ja siten alttiiksi myös väärinkäsityksille. Tärkeintä ei tällöin ole lähtötekstin kontekstiin perustuva referoidun fragmentin ymmärtäminen vaan fragmentin mukauttaminen niin, että se palvelee uuden kontekstinsa argumentaatiota ja rakentaa samalla kuvaa nokkelasta kielenkäyttäjästä. Nettikeskustelussa ääneen pääsemisen edellytyksenä ei olekaan yhteiskunnalliseen asemaan perustuva kielellinen pääoma ja auktoriteetti (vrt. Bourdieu 1982: 103-119), vaan pääosaan asettuu kielellinen kekseliäisyys.

\subsection{Yleiset totuudet}

Ongin (1977) mukaan suullista kulttuuria luonnehtii tiedon kerääntyminen kiteytyneisiin ilmauksiin, kuten sananlaskuihin ja sanontoihin ja yleisinä totuuksina pidettyihin uskomuksiin. Kirjallisessa kulttuurissa tieto taas on varastoitunut tosiasioihin, jotka 
on kirjattu muistiin. Suullinen kulttuuri siis rakentaa totuutta maalaisjärkeen perustuvalla kokemusperäisellä tiedolla, kun taas kirjallinen kulttuuri rakentaa totuutta loogisilla ja koherenteilla argumenteilla. Nettikeskusteluissa tämä rajanveto häilyy, ja kirjallinen perimätieto muuttuu sanonnoiksi, jotka ovat etääntyneet alkuperäisestä kontekstistaan, kuten edellä esitimme. Toisaalta nettikeskustelussa esitetään paljon sellaisia ideologisia uskomuksia ja näkemyksiä todellisuuden rakentumisesta, joita toistamalla keskustelijat rakentavat yleisiä totuuksia.

Muutamia poikkeuksia lukuun ottamatta analysoimaamme viestiketjua luonnehtii yleisenä totuutena esitetty ajatus eli topos, jonka mukaan muslimien oleskelu Suomessa on kielteinen asia ja muodostaa uhkan, jota vastaan on toimittava jollakin tavalla. Kielellisesti toposta rakennetaan muun muassa olla-verbillä muodostetulla suhdeprosessilla (nyt ollaan kusessa. tulijat on kuin paska rattaassa, viesti 14). Tällaisista itsenäisissä lauseissa esiintyvistä suhdeprosesseista ei voi päätellä, kenen näkökulmasta asia esitetään, eikä ole selvää, ottaako puhuja tai kirjoittaja niistä vastuun vai esittääkö hän lausuman yleisenä totuutena. Myös alaluvussa 3.3 käsitellyt tekijän häivyttävät passiivirakenteet, joissa materiaalinen eli tekemistä osoittava prosessi tulkitaan tyypillisesti toistuvana ja tavanomaisena, ovat omiaan esittämään yleisiä totuuksia. Asiaintilaa kuvaavat lisäksi eksistentiaaliset prosessit, joista voidaan joskus jättää verbi pois. Kaikki edellä kuvatut kategoriat esiintyvät seuraavan esimerkin kolmessa viimeisessä virkkeessä.

\section{(13) naisetvaarassa}

2.10.2017 21:39

onko ennätys 7 eri henkilöllisyyttä. tietääkö negri täällä olevien edes oikean henkilöllisyyden ja taustat. puhumattakaan 7 sivupersoonan nimen ja taustat. kyllä nyt päättäjät vastuuseen. eurooppa on turvaton. naisia teurastetaan kuin elukoita. ei mitään ihmisarvoa. (viesti 15)

Kuten edellä on esitetty, koko viestiketju on pitkälti reagointia Marseillessa tapahtunutta terrori-iskua koskevaan uutisointiin ja iskua edeltäneeseen terrori-iskujen kauteen. Esimerkissä 13 uutisen referoinnista on kuitenkin siirrytty sen arvottavaan kommentointiin, jolloin lähestytään yleisenä totuutena esitettyä seikkaa eli toposta. Faktojen ja valeuutisten rajalla häilyvien toposten sekoittuminen onkin eräs tutkimaamme viestiketjua luonnehtivista piirteistä (ns. valeuutisoinnista tarkemmin ks. Haasio, Ojaranta \& Mattila 2017). Uutisen ja kommentin rajankäynti kuvastaa nykyistä viestintäilmastoa laajemminkin: siinä missä tässä aineistossa korostuu intertekstuaalinen suhde uutisista verkkokeskustelun viesteihin, on nykypäivänä tavallista sekin, että uutismedia poimii aineksia sosiaalisesta mediasta (Pöyhtäri ym. 2013: 85, 166).

Suurin osa ketjussa esiintyvistä topoksista liittää keskustelun maahanmuuttodiskurssiin, jossa esiintyy myös avoimen rasistista ideologiaa. Esimerkeissä 3, 6 ja 12 esiintyy tämän aineiston yleisin muslimeja koskeva topos, muslimien väkivaltaisuus. Se on topoksena kaikkiaan yhdeksässä viestissä. Epäinhimillistämisen eli dehumanisaation topos, jossa ihmisryhmä esitetään saastaisena ja alikehittyneenä, esiintyy tässä aineistossa seitsemässä viestissä (esim. sikolätit, sonta, kuppaiset valepukit, paska rat- 
taassa, naisten teurastaminen elukoiden tavoin, islamin kuulumattomuus sivistysvaltioihin). Muut muslimeja koskevat topokset tässä aineistossa ovat paremman elintason perässä tapahtuva maahanmuutto (6 kertaa), epärehellisyys (joka tosin menee sekaisin ulkomaisten terroristien epärehellisyyden kanssa, 4 kertaa) ja muslimien suvaitsemattomuus (4 kertaa). Suomen poliittiseen tilanteeseen liittyvistä topoksista viestiketjussa vallitsevana esiintyy poliitikkojen epäpätevyys ja naiivius, jonka vastakohtana usein esitetään tavallinen kansa (9 kertaa). Sananvapauden rajoittaminen ja rajoittamisen kohteena olevien esittäminen uhreina on aiheena kolmessa viestissä.

Kaiken kaikkiaan koko viestiketjua luonnehtivana topoksena voidaan lisäksi pitää "meidän" ja "heidän/niiden" välistä eroa. Viestiketjussa rakentuu kuva, jossa "me"-ryhmä tietää, mikä on oikein, toimii oikein ja muodostuu oikeanlaisista ihmisistä, kun taas toiseutetut ryhmät (erityisesti muslimit, mutta jossain määrin myös naiivit poliitikot ja ns. suvakit) ovat väärässä, toimivat väärin ja ovat suurelta osin vääränlaisia ihmisiä. Sisäryhmä näyttäytyy uhrina, jolla ei ole valtaa (vrt. Hännikäinen \& Melender 2012: 99), sillä valtaa käyttävät väärin ajattelevat oman kansan edustajat mielipiteillään ja toimillaan sekä väkivaltaiset muslimit teoillaan. Tutkimuksemme vahvistaakin osaltaan Lahden (2019) saamia tuloksia, joiden mukaan vastakkainasetteluiden rakentaminen on laajemminkin yleistä Suomi24-keskustelufoorumin maahanmuuttoa käsittelevissä keskusteluissa.

Merkitykset riippuvat viime kädessä topoksista, joiden taustalla on ideologia (Anscombre 1995: 191-192). Juuri tähän perustuu kielenkäytön affektiivisen ulottuvuuden tunnistaminen myös silloin, kun affektia ei eksplisiittisesti ilmaista - se voidaan päätellä topoksesta, johon viesti liittyy (Amossy 2016: 226). Toposten yhteinen ideologinen kehys liittää yhteen lausumia ja niiden tuottajia (mts. 133) ja vahvistaa näin kielenkäyttötilanteeseen osallistuvien ryhmäidentiteettiä. Tulkinnanvaraiset ilmaukset, joita viestiketjussa on runsaasti, saavat siten merkityksen ketjun yleisestä ideologisesta viitekehyksestä, joka siihen kuuluvine topoksineen on yhtenä tekijänä viestiketjun tekstuaalisen koheesion rakentumisessa. Topoksen toistaminen puolestaan luonnollistaa taustalla olevaa ideologiaa (Simpson 1993: 6).

\section{Päätäntö}

Olemme tässä artikkelissa tarkastelleet, millaisia kielellisiä keinoja käytetään rakentamaan maahanmuuttovastaista ideologiaa Suomi24-keskustelufoorumin eräässä viestiketjussa. Olemme lisäksi analysoineet, kuinka tämän ideologian rakentamisessa pidetään yllä ja hyödynnetään identiteettien vastakkainasettelua sisäryhmän, "meidän suomalaisten", ja ulkoryhmän, "niiden ulkomaalaisten muslimien", välillä. Analyysimme osoittaa, että maahanmuuttovastaisen ideologian ja eri ryhmien vastakkainasettelun rakentaminen on kompleksinen prosessi, joka rakentuu paitsi intra- myös intertekstuaalisesti. Tässä prosessissa oma tehtävänsä on niin kieliopillis-semanttisilla kuin diskurssia ja kontekstia koskevilla osatekijöillä.

Sekä intra- että intertekstuaalisesti rakentuva vastakkainasettelu nivoo viestiketjun osaksi identiteettidiskurssia, sillä identiteetin voidaan katsoa koskevan nimenomaan 
itsen ja toisten sosiaalista asemoimista (Bucholtz \& Hall 2005: 586). Poliittisen diskurssin tutkijan Paul Chiltonin (2004) luoma diskursiivisen tilan perusmalli (basic discourse space model), joka on esitetty kuviossa 1, soveltuu hyvin mallintamaan tapaa, jolla viestiketjussa asemoidaan toiseus suhteessa itseen ja väärä suhteessa oikeaan.

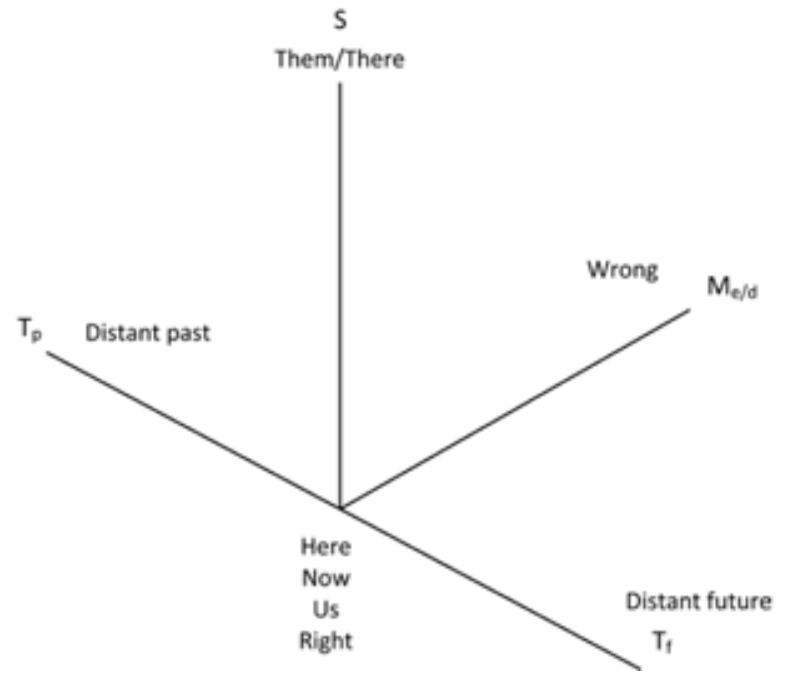

Kuvio 1.

Diskursiivisen tilan perusmalli (Chilton 2004: 336).

Kuviossa on kolme akselia: temporaalinen (T), modaalinen (M) ja sosio-spatiaalinen (S). Puhujan origo eli deiktinen keskus sijoittuu näiden akselien risteyskohtaan, tarkastelupisteeseen, jossa tässä, nyt, me ja oikea yhdistyvät. Mitä kauemmas akselilla mennään puhujan origosta, sitä suurempi on mentaalinen etäisyys. Analysoimassamme viestiketjussa otsikossa esiin nostettua ihmisryhmää (muslimit) edustavat he/ne sijaitsevat varsin etäällä viestiketjun osanottajista eli meistä; he/ne tekevät vääriä tekoja, jotka ovat myös mentaalisesti etäällä siitä, mikä meistä on oikein. Viestiketjussa rakentuu myös sisä- ja ulkoryhmien väliin sijoittuvia toimijoiden joukkoja, kuten poliitikot, jotka kontekstista riippuen voivat joskus edustaa meitä, toisinaan taas heitä/niitä.

Tutkimuksemme edustaa mikrotason analyysia, jossa olemme yhdistäneet useita tulokulmia osoittaaksemme tarkastelemamme tekstikokonaisuuden taustalla olevia laajempia yhteiskunnallisia prosesseja (vrt. Scollon \& Scollon 2004: 8). Tässä lähestymistavassa on vahvuutensa ja heikkoutensa: yhtäältä olemme päässeet tarkastelemaan yhtä esimerkkitekstiä syvällisesti ja monesta eri näkökulmasta, mutta toisaalta saamiemme tulosten yleispätevyyden osoittaminen on tämän aineiston perusteella mahdotonta. Mikrotason analyysi pakottaa tutkijan myös toistamaan tutkimaansa vihapuhetta, mitä voidaan pitää myös vihapuheen levittämisenä (Butler 1997: 163). Olemme tietoisia tästä mahdollisuudesta, mutta korostamme samalla, etteivät esimerkit edusta meidän mielipiteitämme. Vakuuttavan analyysin tueksi on pakko esittää esimerkkejä, joihin analyysi perustuu, ja uuden kontekstinsa murrosvoiman ansiosta 
vihapuhe-esimerkkien voidaan pikemminkin katsoa kääntyvän itseään vastaan (vrt. Derrida 1972: 365-393).

Vaikka keskustelufoorumi on kielenkäyttötilanteena kaukana perinteisistä kielellisen vallan keskipisteistä ja voimakkaasti performatiivisista tekstilajeista (lait, määräykset, poliittiset puheet, perinteiset tiedotusvälineet), sosiaalisella medialla on merkittävä yhteiskunnallinen rooli. Verkkokeskusteluissa yhteiskunnassa vallitsevat ideologiat ja erityisesti ääriajattelu nousevat esiin vapaammin kuin esimerkiksi poliittisessa diskurssissa ja tiedotusvälineissä. Tässä valossa onkin mielenkiintoista huomata, että vaikka keskustelufoorumeita pidettiin aluksi mahdollisuutena entistä laajempaan yhteiskunnalliseen keskusteluun ja mielipiteiden vaihtoon, ainakin tässä viestiketjussa pikemminkin pönkitetään yhtä ideologiaa sen sijaan, että eri mielipiteistä keskusteltaisiin asiallisesti. Siten analyysimme näyttäytyy myös esimerkkinä tavasta, jolla kielellä rakennetaan sosiaalisen median kuplaa - tässä tapauksessa "kantasuomalaista" ideologista kuplaa. Eräs kuplan erityispiirteistä on se, että viestijöillä on jo valmiiksi samankaltainen konteksti, johon kuuluvat muun muassa tietynlaiset asenteet viestiketjun aihetta kohtaan. Vaikka viestijät välillä kommentoivat toistensa viestejä, he lähinnä lisäävät aineksia jo valmiiksi jaettuun kontekstiin. Siksi konteksti ja siihen liittyvät (maahanmuuttovastaiset) asenteet pikemmin vahvistuvat kuin muuttuvat keskustelun aikana. Tämä havainto on linjassa sen kanssa, mitä Lahti (2019) esittää väitöskirjassaan Suomi24-foorumin maahanmuuttokeskustelun retoriikasta: maahanmuuttoa vastustavat keskustelijat tukevat vahvasti toisiaan ja rakentavat yhteistä argumentaatiota ja yhteistä maailmankuvaa, jolloin argumentointi perustuu esisopimuksille ja perusteluille, joita pidetään yhteisenä tietona.

Verkkoviestinnän mahdollistamassa uudenlaisessa viestintäympäristössä ja viestinnän eri tekijöiden rakenteessa myös poliittisen väkivallan riski kasvaa. Poliittisen väkivallan mahdollistavina tekijöinä terrorismin tutkija Leena Malkki (2015) mainitsee muun muassa kokemukset eriarvoisuudesta, pettymyksen perinteisiin poliittisiin vaikutuskeinoihin ja väkivallan sallivan keskusteluilmapiirin voimistumisen. Kaikkia näitä tekijöitä voi havaita analysoimassamme keskustelussa.

Ymmärrys syrjivän kielenkäytön mekanismeista ja niiden aikaansaamista riskeistä on merkittävässä asemassa, jos halutaan parantaa yhteiskunnallista keskusteluilmapiiriä, hillitä vastakkainasetteluja tai nostaa keskustelupalstojen ylläpidon laatua. Analyysimme tarjoaakin aineksia sen ymmärtämiseen, kuinka vihapuheen voisi tunnistaa ja kuinka se voitaisiin määritellä, sillä tutkiessamme identiteettien rakentumista maahanmuuttovastaisessa Suomi24-keskusteluketjussa olemme samalla päätyneet tarkastelemaan myös sitä, millaisia toistuvia ilmiöitä ja argumentatiivisia keinoja verkon vihapuheesta voidaan löytää. Vihapuheen tunnistamisen ongelmia ovat tämän analyysin perusteella muun muassa sanojen vääristely, neutraali nimeäminen, abstraktin substantiivin käyttäminen ihmisreferentin sijaan, nimeämättä jättäminen, kirjoittajapersoonan häivyttäminen ja toisen ajattelijan tekstin lainaaminen. Vihapuheen saavuttamaton ydin näyttäisikin olevan deklaratiivisissa puheakteissa pikemmin kuin avoimissa solvauksissa ja uhkauksissa - erityisesti attributiivisissa prosesseissa, joista mielipiteen ilmaisijan kielellinen toimijuus häivytetään, ja topoksissa, jotka eivät avaudu pelkän kieliopillisen ja sanastollisen analyysin avulla. 


\section{Lähteet}

ADAMEC, LUDWIG 2009: Historical dictionary of Islam. 2. painos. Lanham, MD: Scarecrow Press.

Amossy, Ruth 2016: L'argumentation dans le discours. Paris: Armand Colin.

Amossy, Ruth - Herschberg Pierrot, Anne 1997: Stéréotypes et clichés. Paris: Armand Colin.

Angenot, Marc 1982: La parole pamphlétaire. Typologie des discours modernes. Paris: Payot.

Anscombre, JeAn-Claude 1995: La théorie des topoï. Sémantique ou rhétorique ? - Hermès. La Revue 15 (1) s. 185-198.

ARENDHOLZ, JENNY 2013: (In)appropriate online behavior. A pragmatic analysis of message board relations. Amsterdam: John Benjamins. https://doi.org/10.1075/pbns.229.

Ariel, Mira 1990: Accessing noun-phrase antecedents. London: Routledge. https://doi. org/10.4324/9781315857473.

Assimakopoulos, Stavros - Baider, Fabienne - Millar, Sharon (toim.) 2017: Online hate speech in the European Union. A discourse-analytic approach. Cham: Springer Open. https://doi.org/10.1007/978-3-319-72604-5.

Bahtin, Minail Mihailovitš 1991 [1963]: Dostojevskin poetiikan ongelmia. Suomentaneet Paula Nieminen \& Tapani Laine. Helsinki: Orient Express.

Benveniste, Émile 1971 [1966]: Problems in general linguistics. Miami Linguistic Series No. 8. Kääntänyt Mary Elizabeth Meek. Florida: University of Miami Press.

Bourdieu, Pierre 1982: Ce que parler veut dire. Léconomie des échanges linguistiques. Paris: Fayard.

Bucholtz, Mary - Hall, Kira 2005: Identity and interaction. A sociocultural linguistic approach. - Discourse Studies 7 s. 585-614. https://doi.org/10.1177/1461445605054407.

Butler, Judith 1997: Excitable speech. A politics of the performative. New York: Routledge.

Chilton, Paul 2004: Analysing political discourse. Theory and practice. New York: Routledge.

CORNish, Francis 1999: Anaphora, discourse and understanding. Evidence from English and French. Oxford: Oxford University Press.

DerRidA, JACQues 1972: Marges de la philosophie. Paris: Minuit.

Ducrot, Oswald 1984: Le dire et le dit. Paris: Minuit.

FAIRCLOUgh, Norman 1993: Critical discourse analysis and the marketization of public discourse. The universities. - Discourse and Society 4 s. 133-168. https://doi.org/10.1177/095 7926593004002002.

Foucault, Michel 2005: Tiedon arkeologia. Suomentanut Tapani Kilpeläinen. Tampere: niin \& näin.

— 2014: Diskurssin ei pidä katsoa olevan. Teoksessa Parhaat s. 152-153. Suomentaneet Tapani Kilpeläinen, Simo Määttä \& Johan L. Pii. Tampere: niin \& näin.

FOX, BARBARA 1987: Discourse structure and anaphora. Written and conversational English. Cambridge studies in linguistics 48. Cambridge: Cambridge University Press. https://doi. org/10.1017/CBO9780511627767.

Givón, Thomas 1983: Topic continuity in discourse. A quantitative cross-language study. Amsterdam: John Benjamins. https://doi.org/10.1075/tsl.3.

HaAsio, Ari - Ojaranta, Anu - Mattila, Markku 2017: Valheen lähteillä. Valemedian lähteistö ja sen luotettavuus. - Media \& Viestintä 40 s. 100-121. https://doi.org/10.23983/ mv.67796.

Hakulinen, Auli - Karlsson, Fred 1979: Nykysuomen lauseoppia. Suomalaisen Kirjalli- 
suuden Seuran Toimituksia 350. Helsinki: Suomalaisen Kirjallisuuden Seura.

Hakulinen, Auli - Laitinen, Lea 2008: Anaforinen nolla. Kielioppia ja affekteja. - Virittäjä 112 s. 162-185.

Halliday, M. A. K. 1978: Language as social semiotic. The social interpretation of language and meaning. London: Edward Arnold.

Hart, Christopher 2015: Discourse. - Ewa Dabrowska \& Dagmar Divjak (toim.), Handbook of cognitive linguistics s. 322-346. Berlin: De Gruyter Mouton. https://doi. org/10.1515/9783110292022-016.

Helasvuo, Marja-Liisa - Johansson, Marjut - Tanskanen, Sanna-Kaisa (toim.) 2014: Kieli verkossa. Näkökulmia digitaaliseen vuorovaikutukseen. Suomalaisen Kirjallisuuden Seuran Toimituksia 1402. Helsinki: Suomalaisen Kirjallisuuden Seura.

Heller, Monica - Pietikäinen, Sari - Pujolar, Joan (toim.) 2017: Critical sociolinguistic research methods. Studying language issues that matter. New York: Routledge.

Herneaho, Irina 2018: Maahanmuuttodiskurssit eduskuntapuolueiden vuoden 2015 vaalimateriaaleissa. - Virittäjä 122 s. 187-223. https://doi.org/10.23982/vir.66907.

HerRING, SUSAN 2004: Computer-mediated discourse analysis. An approach to researching online communities. - Sasha Barab, Rob Kling \& James Gray (toim.), Designing for virtual communities in the service of learning s. 338-376. New York: Cambridge University Press. https://doi.org/10.1017/CBO9780511805080.016.

HÄмÄLÄINEN, LAsSE 2019: Nimet verkossa. Tutkimus verkkoyhteisöjen käyttäjänimistä ja virtuaalisen minigolfpelin radannimistä. Helsinki: Helsingin yliopisto. http://urn.fi/ URN:ISBN:978-951-51-5259-6.

Hännikäinen, Timo - Melender, Tommi 2012: Liberalismin petos. Esseistinen pamfletti. Helsinki: WSOY.

Jantunen, Jarmo Harri 2018: Homot ja heterot Suomi24:ssä. Analyysi digitaalisista diskursseista. - Puhe ja kieli 38 s. 3-22. https://doi.org/10.23997/pk.65488.

Johansson, Marjut - Jantunen, Jarmo Harri - Heimo, Anne - Ahonen, Mirka - Laippala, Veronika 2018: Verkkokeskustelujen kansa. Korpusavusteinen diskurssianalyysi Suomi24-keskustelupalstasta. - Sananjalka 6o s. 96-117. https://doi.org/10.30673/ sja.69963.

KajÁn, Eva 2017: Hate online. Anti-immigration rhetoric in Darknet. - Nordia Geographical Publications 46 (3) s. 3-22.

KеLOMÄKI, TAPANI 2019: Suomen passiivin ja impersonaalin määritelmistä ja keskinäisistä suhteista. - Virittäjä 123 s. 110-134. https://doi.org/10.23982/vir.49512.

Ketola, Anni 2013: Plussatuulia ja muita odottajan sanoja. - Kielikello 1/2013.

KLEINKE, SONJA 2010: Interactive aspects of computer-mediated communication. Disagreement in an English and German public news group. - Sanna-Kaisa Tanskanen, MarjaLiisa Helasvuo, Marjut Johansson \& Mia Raitaniemi (toim.), Discourses in interaction s. 195-222. Amsterdam: John Benjamins. https://doi.org/10.1075/pbns.203.15kle.

Kristeva, Julia 1969: Sèméiotikè. Recherches pour une sémanalyse. Paris: Seuil.

$\mathrm{KS}=$ Kielitoimiston sanakirja 2018. Helsinki: Kotimaisten kielten keskus. URN:NBN:fi:kotus-201433. Verkkojulkaisu HTML. Päivitettävä julkaisu. Päivitetty 6.6.2018 (12.10.2019).

Lagus, Krista - Pantzar, Mika - Ruckenstein, Minna - Ylisiurua, MarjoriikKA 2016: SUOMI24. Muodonantoa aineistolle. Kuluttajatutkimuskeskus, Valtiotieteellisen tiedekunnan julkaisuja 2016:10. Helsinki: Helsingin yliopisto. https://blogs.helsinki.fi/ citizenmindscapes/files/2016/05/257383_HY_VALT_suomi24_muodonantoa_aineistolle. pdf (23.4.2019). 
Laнti, Еммі 2019: Maahanmuuttokeskustelun retoriikkaa. Helsinki: Helsingin yliopisto. http://urn.fi/URN:ISBN:978-951-51-5707-2.

Laitinen, Lea 1995: Nollapersoona. - Virittäjä 99 s. 337-357.

— 2006: Zero person in Finnish. A grammatical resource for construing human reference. - Lyle Campbell \& Marja-Liisa Helasvuo (toim.), Grammar from the human perspective. Case, space, and person s. 209-231. Amsterdam: John Benjamins. https://doi.org/10.1075/ cilt.277.15lai.

Lehti, Lotta - Eronen-Valli, Maria 2018: Diskurssintutkimuksen menetelmiä digitaalisen retoriikan tutkimuksessa. - Lauri Haapanen, Liisa Kääntä \& Lotta Lehti (toim.), Dirskurssintutkimuksen menetelmistä s. 156-176. AFinLA-e. Soveltavan kielitieteen tutkimuksia 11. https://doi.org/10.3066o/afinla.69104.

LEWANDOWSKA-TOMASZCZYK, BARBARA 2017: Incivility and confrontation in online conflict discourses - Lodz Papers in Pragmatics 13 s. 347-367.

Malk ki, Leena 2015: Suomi ja poliittinen väkivalta. Kaltevalla pinnalla. - Politiikasta. Tutkimuksia ajankohtaisesti ja ajattomasti. https://politiikasta.fi/suomi-ja-poliittinen-vakivalta-kaltevalla-pinnalla/ (23.4.2019).

Mӓ̈̈ттё Sıмо 2004: Dialect and point of view. The ideology of translation in The Sound and the Fury in French. - Target. International Journal of Translation Studies 16 s. 319-339.

Ong, WALter 1977: Interfaces of the word. Ithaca, N.Y.: Cornell University Press.

PAAKKInen, Ilse 2017: Vihapuheen anatomia. - Sosiaalietiikka.fi. https://blogs.helsinki.fi/ socialethics/artikkelit/vihapuheen-anatomia/ (23.4.2019).

Pietikärnen, SARi 200o: Kriittinen diskurssintutkimus. - Kari Sajavaara \& Arja PiirainenMarsh (toim.) Kieli, diskurssi ja yhteisö s. 191-217. Jyväskylän yliopisto, Soveltavan kielentutkimuksen keskus. Jyväskylä.

Pietikëinen, SARi - Mäntynen, Anne 2009: Kurssi kohti diskurssia. Tampere: Vastapaino.

Pye, Michael 1993: MacMillan dictionary of religion. New York: Palgrave MacMillan. https:// doi.org/10.1057/9780230379411.

Pälli, PekKa 2003: Ihmisryhmä diskurssissa ja diskurssina. Tampere: Tampereen yliopisto. http://urn.fi/urn:isbn:951-44-5580-o.

PÄrssinen, Minna 2017: Marseillessa puukkohyökkäys juna-asemalla, kolme kuoli. Yle uutiset. https://yle.fi/uutiset/3-9861125 (15.2.2019).

Pöyhtäri, Reeta - Haara, Paula - Raittila, Pentti 2013: Vihapuhe sananvapautta kaventamassa. Tampere: Tampere University Press. http://urn.fi/ URN:ISBN:978-951-44-9249-5.

Raamattu 1992. Suomen evankelis-luterilaisen kirkon vuonna 1992 käyttöön ottama Uuden ja Vanhan Testamentin suomennos. https://raamattu.fi (16.2.2019).

Reisigl, Martin - Wodak, Ruth 2001: Discourse and discrimination. Rhetorics of racism and antisemitism. London: Routledge. https://doi.org/10.4324/9780203993712.

Rojola, Lea - Laitinen, LeA 1998: Keskusteluja performatiivuudesta. - Lea Rojola \& Lea Laitinen (toim.), Sanan voima. Keskusteluja performatiivisuudesta s. 7-33. Tietolipas 160. Helsinki: Suomalaisen Kirjallisuuden Seura.

Rosenberg, Jutta 2018: Täti tulee kylään -ilmaisu vauva.fi-palstalla. Esitelmä XLV Kielitieteen päivillä. Helsinki, 7.-9.5.2018.

SAVOlainen, LaURA 2018: Yksin yhdessä. Tunnetoisto vertaistukipalstalla. - Citizen Mindscapes -blogi. https://blogs.helsinki.fi/citizenmindscapes/2018/03/o6/yksin-yhdessatunnetoisto-vertaistukipalstalla/ (23.4.2019). 
Saresma, Tuija 2012: "Miesten tasa-arvo" ja kaunapuhe blogikeskustelussa. - Hannele Harjunen \& Tuija Saresma (toim.), Sukupuoli nyt! Purkamisia ja neuvotteluja s. 13-34. Jyväskylä: Kampus kustannus.

SARESMA, TuIJA 2017: Sananvapaus, vihapuhe ja sananvastuu. - Kari Enqvist, Ilari Hetemäki \& Teija Tiilikainen (toim.), Kaikki vapaudesta s. 35-50. Helsinki: Gaudeamus.

Scollon, Ron -Scollon, Suzie Wong 2004: Nexus analysis. Discourse and the emerging internet. London: Routledge.

Simpson, Paul 1993: Language, ideology and point of view. London: Routledge.

Tiainen, Outi 1998: Referenttien kuljettaminen diskurssissa. - Virittäjä 102 s. 498-528.

Tuomarla, Ulla 2016: Perpanssihavaintoja. - Citizen Mindscapes -blogi. https://blogs.helsinki.fi/citizenmindscapes/2016/o1/21/perpanssihavaintoja/ (23.4.2019).

2019: Vihapuhe ei ole aina vihaista puhetta. - Politiikasta. Tutkimuksia ajankohtaisesti ja ajattomasti. https://politiikasta.fi/vihapuhe-ei-ole-aina-vihaista-puhetta/ (23.4.2019).

Varjo, Mikael - Suomalainen, Karita 2018: From zero to 'you' and back. A mixed methods study comparing the use of two open personal constructions in Finnish. - Nordic Journal of Linguistics 41 s. 333-366. https://doi.org/10.1017/So332586518000215.

Virtanen, Miкко T. 2018: Terveysaiheisista kokemuksista keskustelu anonyymilla verkkopalstalla. Esitelmä XLV Kielitieteen päivillä. Helsinki, 7.-9.5.2018.

Virtanen, Miкко T. - Kä̈̈ntä, LiIsa 2018: At the intersection of text and conversation analysis. Analysing asynchronous online written interaction. - Lauri Haapanen, Liisa Kääntä \& Lotta Lehti (toim.), Dirskurssintutkimuksen menetelmistä s. 137-155. AFinLA-e. Soveltavan kielitieteen tutkimuksia 11. https://doi.org/10.3066o/afinla.69081.

Viтıкка, Elina 2014: Vihapuhetta vai ei? Reseptioanalyysia vihapuheen kielestä ja kontekstista. Suomen kielen pro gradu -tutkielma. Helsingin yliopisto.

VisK = Hakulinen, Auli -Vilikuna, Maria - Korhonen, Rittta - Koivisto, Vesa - Heinonen, Tarja Riitta - Alho, Irja 2004: Iso suomen kielioppi. Helsinki: Suomalaisen Kirjallisuuden Seura. Verkkoversio. http://scripta.kotus.fi/visk (5.3.2019).

WikiIslam 2019. Allahu akbar. https://wikiislam.net/wiki/Allahu_Akbar (16.2.2019).

Wodak, Ruth - Dijk, Teun A. van (toim.) 200o: Racism at the top. Parliamentary discourses on ethnic issues in six European states. Klagenfurt: Drava. 


\section{Constructing anti-immigration ideology and group identity in an online conversation thread on the Suomiz4 discussion board}

This article examines the linguistic features of an anti-immigration discussion in the Suomi24 online discussion forum. The article is based on a case study focusing on a conversation thread that was started in October 2017. Initially, the thread consisted of 40 comments, 13 of which were eliminated by the forum's moderators. The present analysis aims to outline the means by which an anti-immigration ideology is built into the data. Particular attention is paid to the lexical, syntactic, textual, and discursive tools through which the participants in the thread construe different group identities, a strategy that eventually leads to an important polarisation between 'them' and 'us' . A discourse-analytical micro-level analysis is used to unravel the broader societal processes underlying the discussion.

The article demonstrates how the construal of polarisation between different group identities plays a crucial role in creating anti-immigration ideology both by intratextual and intertextual means. As shown in the concluding chapter, Chilton's (2004) basic discourse space model may be used to illustrate this construal of mental distance between 'them' (immigrants who are targeted as unwanted objects) and 'us' (discussion participants).

The intratextual analysis focuses on NPs, anaphoric expressions, and open personal constructions used to refer to groups of people, whereas the intertextual analysis concentrates on speech and thought representation and intertextual links to current news, culturally significant texts, and stereotypical topoi.

The article shows that there is a strong connection between the linguistic construction of group identities and discriminatory speech, a category also comprising hate speech. Furthermore, the article provides new insights into several recurring linguistic and argumentative phenomena present in hate speech. In social media, it is easy to spread hate speech, which is why such informal channels in the public sphere have become a social challenge. Preventing hate speech requires understanding the mechanisms of discriminatory language use. 


\section{Maahanmuuttovastaisen ideologian ja ryhmäidentiteetin rakentuminen Suomi24-keskustelussa}

Artikkeli käsittelee maahanmuuttovastaisen keskustelun kielellisiä piirteitä Suomi24keskustelufoorumilla. Aihetta lähestytään tapaustutkimuksen näkökulmasta. Tutkimuksen aineistona on syksyllä 2017 Suomi24-foorumilla käyty keskustelu. Artikkelin tavoitteena on kuvata niitä kielellisiä keinoja, joilla tutkimuksen kohteena olevassa keskusteluketjussa rakennetaan maahanmuuttovastaista ideologiaa. Huomio kohdistuu erityisesti siihen, millaisin leksikaalisin, syntaktisin, tekstuaalisin ja diskursiivisin keinoin keskustelun osallistujat rakentavat erilaisia ryhmäidentiteettejä ja polarisaatiota "meidän" ja "heidän/niiden" välillä. Lähestymistapa on diskurssianalyyttinen, ja mikrotason analyysi pyrkii osoittamaan tekstikokonaisuuden taustalla olevia laajempia yhteiskunnallisia prosesseja.

Artikkelissa esitetään, että eri ryhmien vastakkainasettelulla on keskeinen asema maahanmuuttovastaisen ideologian rakentamisessa. Aineistossa vastakkainasettelua rakennetaan sekä intra- että intertekstuaalisin keinoin. Intratekstuaalisiin keinoihin lukeutuvat erilaisten nimeävien ja viittaavien ilmausten käyttö ja ketjuttaminen sekä avointen ja impersonaalisten ilmausten käyttö. Intertekstuaalisia keinoja puolestaan ovat sanontojen ja ajankohtaisten uutisten referointi sekä tiettyjen vihamielisten toposten toistaminen. Artikkelissa osoitetaan, että aineistossa ryhmäidentiteettien kielellisellä rakentamisella on vahva yhteys syrjivään puheeseen, jollaiseksi myös vihapuhe voidaan lukea. Artikkelissa todetaan, että Chiltonin (2004) diskursiivisen tilan perusmalli soveltuu hyvin kuvaamaan keskustelun osallistujien ("me") ja syrjivän puheen kohteena olevien ("he"/"ne") välistä diskurssitason polarisaatiota ja mentaalista etäisyyttä.

Artikkeli tuo uutta tietoa siitä, millaisia toistuvia ilmiöitä ja argumentatiivisia keinoja vihapuheesta on löydettävissä. Sosiaalisessa mediassa on helppo levittää vihapuhetta, minkä vuoksi Suomi24:n kaltaiset kanavat ovat muodostuneet yhteiskunnalliseksi haasteeksi. Vihapuheen ehkäiseminen edellyttää syrjivän kielenkäytön mekanismien ymmärtämistä.

Kirjoittajien yhteystiedot:

etunimi.maatta@helsinki.fi

etunimi.m.suomalainen@utu.fi

etunimi.tuomarla@helsinki.fi

Simo Määttä on käännöstieteen apulaisprofessori Helsingin yliopistossa. Karita Suomalainen on väitöskirjatutkija Turun yliopistossa. Ulla Tuomarla on ranskan kääntämisen yliopistonlehtori Helsingin yliopistossa. 